\title{
Glacial fluctuations of the Indian monsoon and their relationship with North Atlantic climate: new data and modelling experiments
}

\author{
C. Marzin ${ }^{1, *}$, N. Kallel ${ }^{2}$, M. Kageyama ${ }^{1}$, J.-C. Duplessy ${ }^{3}$, and P. Braconnot ${ }^{1}$ \\ ${ }^{1}$ Laboratoire des Sciences du Climat et de l'Environnement/IPSL, CEA-CNRS-UVSQ - UMR8212, CE Saclay, l'Orme des \\ Merisiers, 91191 Gif-sur-Yvette Cedex, France \\ ${ }^{2}$ Université de Sfax, Faculté des Sciences, Laboratoire GEOGLOB, BP 802, 3038 Sfax, Tunisia \\ ${ }^{3}$ Laboratoire des Sciences du Climat et de l'Environnement/IPSL, CEA-CNRS-UVSQ - UMR8212, Bâtiment 12, Parc du \\ CNRS, 91198 Gif sur Yvette cedex, France \\ *now at: Met Office, Exeter, UK
}

Correspondence to: C. Marzin (charline.marzin@metoffice.gov.uk)

Received: 31 July 2012 - Published in Clim. Past Discuss.: 18 December 2012

Revised: 30 April 2013 - Accepted: 30 July 2013 - Published: 12 September 2013

\begin{abstract}
Several paleoclimate records such as from Chinese loess, speleothems or upwelling indicators in marine sediments present large variations of the Asian monsoon system during the last glaciation. Here, we present a new record from the northern Andaman Sea (core MD77-176) which shows the variations of the hydrological cycle of the Bay of Bengal. The high-resolution record of surface water $\delta^{18} \mathrm{O}$ dominantly reflects salinity changes and displays large millennial-scale oscillations over the period 40000 to $11000 \mathrm{yr}$ BP. Their timing and sequence suggests that events of high (resp. low) salinity in the Bay of Bengal, i.e. weak (resp. strong) Indian monsoon, correspond to cold (resp. warm) events in the North Atlantic and Arctic, as documented by the Greenland ice core record. We use the IPSL_CM4 AtmosphereOcean coupled General Circulation Model to study the processes that could explain the teleconnection between the Indian monsoon and the North Atlantic climate. We first analyse a numerical experiment in which such a rapid event in the North Atlantic is obtained under glacial conditions by increasing the freshwater flux in the North Atlantic, which results in a reduction of the intensity of the Atlantic meridional overturning circulation. This freshwater hosing results in a weakening of the Indian monsoon rainfall and circulation. The changes in the continental runoff and local hydrological cycle are responsible for an increase in salinity in the Bay of Bengal. This therefore compares favourably with the new sea water $\delta^{18} \mathrm{O}$ record presented here and the hypothesis of synchronous cold North Atlantic and weak Indian monsoon
\end{abstract}

events. Additional sensitivity experiments are produced with the LMDZ atmospheric model to analyse the teleconnection mechanisms between the North Atlantic and the Indian monsoon. The changes over the tropical Atlantic are shown to be essential in triggering perturbations of the subtropical jet over Africa and Eurasia, that in turn affect the intensity of the Indian monsoon. These relationships are also found to be valid in additional coupled model simulations in which the Atlantic meridional overturning circulation (AMOC) is forced to resume.

\section{Introduction}

During the last glaciation, the presence of large ice sheets and reduced atmospheric $\mathrm{CO}_{2}$ concentration resulted in a drier climate and weaker monsoon systems over Asia, as observed in several paleoclimate records. Modelling experiments (e.g. Yanase and Abe-Ouchi, 2007) have shown that a reduction in moisture transport resulted in less precipitation over East Asia at the Last Glacial Maximum (LGM, 21000 years ago). Results from the Paleoclimate Modeling Intercomparison Project Phase 2 (PMIP2) indicate that the Indian monsoon rainfall was reduced in all models in the LGM experiments (by as much as $1.7 \mathrm{~mm} \mathrm{day}^{-1}$, Braconnot et al., 2007) due to prescribed LGM ice sheets and atmospheric $\mathrm{CO}_{2}$ concentration conditions (differences in orbital forcing are small). 
However, conditions prevailing during the LGM are not representative of the whole glaciation. The climate of the last glaciation was characterized by rapid climate changes in the North Atlantic/Greenland region associated to the Heinrich and Dansgaard-Oeschger (D-O) events (Heinrich, 1988; Bond et al., 1992; Broecker et al., 1992; Dansgaard et al., 1993; Grootes et al., 1993; Meese et al., 1997). Correlative climate changes have been identified in high-resolution climate records from areas as distant as Santa Barbara Basin (Behl and Kennett, 1996), western and southern Europe (Thouveny et al., 1994; Allen et al., 1999), Socotra Island in the Arabian Sea (Burns et al., 2003), China (Wang et al., 2001) and Antarctica (EPICA Community Members, 2006). The abrupt changes in the North Atlantic climate have been associated with changes in the Atlantic meridional overturning circulation (AMOC) (McManus et al., 1999; Elliot et al., 2002; McManus et al., 2004; Stocker and Johnsen, 2003). The Asian monsoon, which is sensitive to orbitally controlled changes of insolation (Xiao et al., 1999; Rousseau and Kukla, 2000) also varied on millennial timescales as shown by speleothem (Wang et al., 2001) and marine sediment (Altabet et al., 2002) records. The Indian monsoon has also been suggested to vary on these timescales. Kudrass et al. (2001) present a record from the northern Bay of Bengal which shows large hydrological perturbations at a millennial timescale comparable to the North Atlantic. They establish their chronology with the Toba ash marker and by assuming that Dansgaard-Oeschger cycles, as described by the GISP2 $\delta^{18} \mathrm{O}$ record (Grootes et al., 1993), are anti-correlated with their $\delta^{18} \mathrm{O}$ record from the Bay of Bengal. The Bay of Bengal, which receives the outflow of major rivers draining the Himalayan mountains and the Indian subcontinent, is very sensitive to changes in the hydrological cycle and continental runoff in South Asia (Prell et al., 1980; Duplessy, 1982).

Here, we have measured the surface water oxygen isotope composition, which we interpret as salinity variations, recorded in a core raised from the southwest sector of the low surface salinity tongue of the northern Andaman Sea, an area which today directly receives the discharge of the Irrawady and Salween rivers. We confirm that, as for previous high-resolution records of the glacial Asian monsoon, the Indian monsoon fluctuates at the millennial timescale during the last glacial period. Furthermore, our chronological constraints are compatible with these fluctuations being simultaneous with the abrupt climate changes recorded in the North Atlantic, with North Atlantic/Greenland cold (resp. warm) events being associated with weak (resp. strong) Indian monsoon. To better understand this relationship, we have turned to modelling experiments to study the potential mechanisms for such a teleconnection between abrupt climatic changes in the North Atlantic and the Indian monsoon.

Understanding this teleconnection between the North Atlantic/Arctic climate and the Indian monsoon intensity is a challenge both for future and past climate changes (Khare, 2008). More generally, the tropical/extratropical teleconnec- tions related to the abrupt climate changes of the last glacial period are not well understood, as underlined in the review by Clement and Peterson (2008). The teleconnection mechanisms explaining the correlative rapid climate variations between the North Atlantic and the Indian monsoon region in the past have been investigated through modelling experiments mostly under present-day climate conditions (Vellinga and Wood, 2002; Zhang and Delworth, 2005; Lu and Dong, 2008). Zhang and Delworth (2005) analysed the tropical response to a weakened AMOC and suggested that the Indian monsoon is weakened due to a weakening of the Walker circulation in the southern tropical Pacific. Lu and Dong (2008) found that an atmospheric teleconnection with the eastern and central North Pacific and an atmosphere-ocean interaction in the tropical North Pacific play the most important role for modulating the strength of the Indian monsoon. Using a model of intermediate complexity, Jin et al. (2007) also suggest that the Asian monsoon circulation is weakened during Heinrich events of the last glacial age.

In addition, several studies have analysed the relationship between a warm phase of the North Atlantic Multidecadal Oscillation (AMO) and a strong Indian monsoon (Zhang and Delworth, 2006; Goswami et al., 2006; Lu et al., 2006; Li and Harrison, 2008; Feng and $\mathrm{Hu}, 2008$ ). Using observations, Goswami et al. (2006) and Feng and Hu (2008) propose a link between the North Atlantic surface temperature and the Indian monsoon intensity through a physical mechanism affecting the meridional gradient of upper tropospheric temperature between the Tibetan Plateau and the tropical Indian Ocean. This meridional gradient of temperature has been shown to be an indicator of the timing and intensity of the summer monsoon season (He et al., 2003; Goswami and Xavier, 2005). At the interannual timescale, Ding and Wang (2005) show that fluctuations of the Indian monsoon can be connected to the variability of the Northern Hemisphere mid-latitude summer circulation, which is strongest along the wave guide provided by the Northern Hemisphere summer jet stream. Ding and Wang (2007) extend this concept at the intraseasonal timescale. On the other hand, Kucharski et al. (2008) use observational datasets to analyse the Atlantic contribution to the Indian monsoon interannual variability. They show that if the ENSO (El Niño Southern Oscillation)-forced variability is subtracted, the strong Indian monsoon years correspond to cold south equatorial Atlantic sea-surface temperatures (SSTs). Kucharski et al. (2009) and Losada et al. (2010) also highlight the teleconnection between the tropical Atlantic and the Indian monsoon circulation at shorter timescales. By using an atmospheric general circulation model to perform sensitivity experiments to SST anomalies in the north and the south tropical Atlantic, they find the south tropical Atlantic sea-surface temperatures to be determinant in the variations of the Indian monsoon. The south tropical Atlantic SST anomalies trigger changes in atmospheric convective activity over this region. The response of the upper atmosphere circulation is in agreement 
with the Gill-Matsuno mechanism, forming a quadrupole in the $200 \mathrm{hPa}$ eddy streamfunction which affects the Indian monsoon circulation and convective activity over India. The relationship is such that a warm SST anomaly over the south tropical Atlantic triggers a decrease in the Indian monsoon.

Modelling experiments usually represent abrupt glacial climate changes as responses to fluctuations of the AMOC triggered by freshwater discharges in the North Atlantic as reviewed in Clement and Peterson (2008) and Kageyama et al. (2010). Several general circulation models have now been used for such glacial freshwater hosing experiments and obtain a reduction of the Indian monsoon when the AMOC weakens (Kageyama et al., 2009; Merkel et al., 2010; Otto-Bliesner and Brady, 2010; Kageyama et al., 2013). Kageyama et al. (2009) use the IPSL_CM4 oceanatmosphere coupled model and show that for this model a collapse of the AMOC under glacial conditions leads to a significant weakening of the Indian monsoon. This weakening appears to be related to the upper tropospheric cooling to the North of the Indian subcontinent, that is occurring simultaneously with the AMOC weakening. Following this previous study, we focus here on an analysis of the impact of an AMOC collapse on the Indian monsoon and on the hydrological cycle of the Bay of Bengal in our original coupled experiment. It is difficult to discern the teleconnection mechanisms between the North Atlantic and the Indian monsoon region from these coupled experiments alone because the weakening of the AMOC affects SSTs over all oceans, including the North and the tropical Atlantic that are both presumed to be key regions for the Indian monsoon. We therefore performed additional sensitivity experiments using the atmospheric component of our coupled model, in order to investigate which region of SST changes has the strongest impact on monsoon changes and to constrain the mechanisms for this North Atlantic/Indian monsoon teleconnection. This allows us to compare our results, obtained for a glacial base state, with similar experiments run to study the present-day monsoon variability (e.g. Kucharski et al., 2009). We then investigate if the relationship we find between tropical SST changes and those in Indian monsoon precipitation holds in additional coupled model experiments in which we force the AMOC to recover.

Section 2 discusses the method and the results of the northern Andaman Sea record for the last $40000 \mathrm{yr}$. The experiment in which we simulate the AMOC collapse and its impact on the Indian monsoon is presented in Sect. 3, as well as the additional sensitivity experiments run with the atmosphere general circulation model and the coupled model. The study is discussed and concluded in Sect. 4.

\section{Indian monsoon variability in the $40000 \mathrm{yr}$ record in the Bay of Bengal}

\subsection{Material and methods}

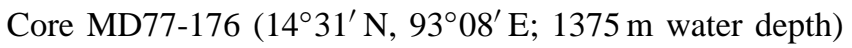
has been selected to estimate surface salinity variations in the Bay of Bengal (Fig. 1). This core, which is located in the southwest sector of the present low surface salinity tongue of the northern Andaman Sea, also records the extreme dryness of the LGM Asian monsoon climate (Duplessy, 1982) and should be very sensitive to fluctuations of the hydrological cycle and continental runoff in the Irrawady-Salween drainage basin.

Oxygen isotope measurements $\left(\delta^{18} \mathrm{O}\right)$ were made on planktonic foraminifera Globigerinoides ruber (Fig. 2). Shells were ultrasonically cleaned in a methanol bath to remove clays and other impurities. They were roasted under vacuum at $380^{\circ} \mathrm{C}$ during $45 \mathrm{~min}$ to eliminate organic matter. Analyses were performed at LSCE on Elementar IsoPrime and Finnigan Delta+ and MAT251 mass spectrometers. All results are expressed as $\delta^{18} \mathrm{O}$ in \%o versus PDB via the calibration with respect to the international standards NBS-19 and NBS-18. The analytical reproducibility as determined from replicate measurements of an internal standard is $\pm 0.05 \%$ (1sigma). The $\delta^{18} \mathrm{O}$ values of planktonic foraminifera record changes in both the oxygen isotope composition of sea surface water $\delta^{18} \mathrm{O}$ (hereafter $\delta^{18} \mathrm{O}_{\mathrm{sw}}$ ) and the isotopic fractionation between calcium carbonate and water, which depends upon the temperature at which foraminifera have formed their shell (Epstein et al., 1953; Shackleton, 1974).

In core MD77-176, SST estimates were derived from foraminiferal counts, using the modern analogue technique (Hutson, 1979; Prentice, 1980; Overpeck et al., 1985). The squared chord distance dissimilarity coefficient was used to measure the mean degree of dissimilarity between each fossil assemblage and the modern analogues. This dissimilarity coefficient $d_{\mathrm{ij}}$ is defined as the squared chord distance between the fossil sample $i$ and the modern sample $j: d_{i j}=$ $\Sigma_{k}\left(p_{i k}^{1 / 2}-p_{i k}^{1 / 2}\right)^{2}$, where $p$ is the proportion of species $k$. In our record, the dissimilarity coefficient never exceeds 0.16 and the ten best modern analogues were selected to estimate past SST with a statistical error smaller than $1{ }^{\circ} \mathrm{C}$ at $1 \sigma$ (Fig. 2).

The SST record exhibits no significant changes from the glacial period to the Holocene except for two short cooling events of about 0.5 to $1{ }^{\circ} \mathrm{C}$ (Fig. 2) at depths which correspond to the beginning of the Holocene, at around 11 and $9.5 \mathrm{cal} \mathrm{kyr} \mathrm{B.P} \mathrm{(see} \mathrm{Fig.} \mathrm{3a} \mathrm{for} \mathrm{the} \mathrm{age} \mathrm{model).} \mathrm{These} \mathrm{results}$ are consistent with all SSTs reconstructed using planktonic foraminiferal assemblages for this region (Cullen, 1981; Barrows and Juggins, 2005), but contrast with the 2 to $3^{\circ} \mathrm{C}$ cooling inferred for the last glaciation from $\mathrm{Mg} / \mathrm{Ca}$ and $U_{37}^{k} \mathrm{SST}$ data in the same area (Rashid et al., 2007; Kudrass et al., 


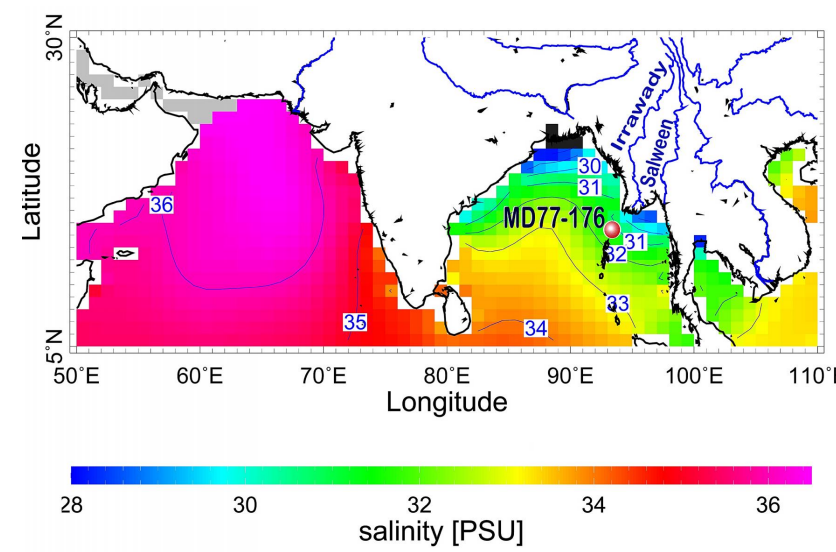

Fig. 1. Location map of the sediment core MD77-176 in the Bay of Bengal: $14^{\circ} 31^{\prime} \mathrm{N}, 93^{\circ} 08^{\prime} \mathrm{E} ; 1375 \mathrm{~m}$ water depth. Superimposed on the map is the present-day annual mean surface salinity of the northern Indian Ocean (data from Levitus et al., 1994).

2001). Considering the results from these geochemical techniques, SST changes within the last glaciation never exceed $2{ }^{\circ} \mathrm{C}$. Observed changes in the foraminiferal $\delta^{18} \mathrm{O}$ record of core MD77-176 are of about 2\%o from glacial to Holocene periods and of about $1 \%$ within the last glaciation. This cannot be explained by 2 or $3{ }^{\circ} \mathrm{C}$ changes in SST because the isotopic effect of such temperature changes cannot be larger than 0.5 to $0.75 \%$ o. On the other hand, in the literature, $\mathrm{Mg} / \mathrm{Ca}$ measurements in Bay of Bengal cores were performed on G. ruber but $\mathrm{Mg} / \mathrm{Ca}$ changes also strongly depend on parameters other than temperature, noticeably salinity and carbonate ion content (Mathien-Blard and Bassinot, 2009). In addition, we note that the $\mathrm{Mg} / \mathrm{Ca} \mathrm{SST}$ record obtained in the northern Bay of Bengal by Rashid et al. (2007) displays no significant changes within the last glacial. This indicates that the millennial variations in $G$. ruber $\delta^{18} \mathrm{O}$ values are not generated by SST changes. The foraminiferal $\delta^{18} \mathrm{O}$ record can thus be considered as a good approximation of the changes in the oxygen isotope composition of the surface water at the location of our core.

Sea water $\delta^{18} \mathrm{O}$ variations directly reflect those of surface water $\delta^{18} \mathrm{O}$ due to both global ice volume changes (Emiliani, 1954) and local freshwater budget (Precipitation + Runoff - Evaporation) variations (Craig and Gordon, 1965; Delaygue et al., 2001). In order to subtract the global ice volume record (Waelbroeck et al., 2002) from the $\delta^{18} \mathrm{O}$ record and to estimate the $\delta^{18} \mathrm{O}_{\mathrm{sw}}$ anomaly (change in the local $\delta^{18} \mathrm{O}_{\mathrm{sw}}$ with respect to modern conditions), we generated an absolute chronology using AMS radiocarbon dating on monospecific (G. ruber) planktonic foraminiferal samples. For the last $20 \mathrm{kyr},{ }^{14} \mathrm{C}$ ages have been converted into calendar ages using the Calib 4.1 program (Stuiver and Reimer, 1993; Stuiver et al., 1998), which includes a correction for the ocean surface reservoir age (Broecker and Peng, 1982). This correction was assumed to be constant and equal to

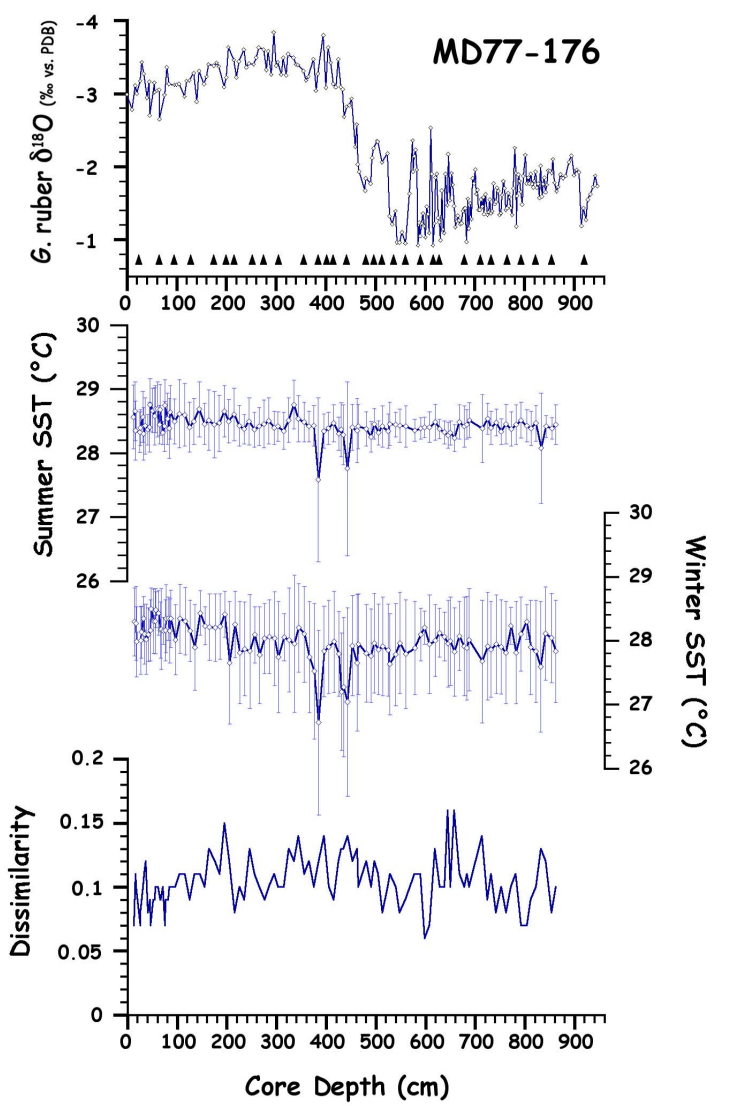

Fig. 2. Depth-age plots for core MD77-176. From top to bottom: $\delta^{18} \mathrm{O}$ of $G$. ruber, reconstructions of summer sea surface temperatures (SST) and winter SST with error bars and dissimilarity coefficients between fossil assemblages and the modern analogues.

$400 \mathrm{yr}$ because air-sea exchanges have always been high in tropical waters. The conversion of ${ }^{14} \mathrm{C}$ ages to calendar ages is less accurate for ages older than $20 \mathrm{kyr}^{14} \mathrm{C} \mathrm{BP}$, because the ${ }^{14} \mathrm{C}$ production rates in the upper atmosphere experienced major changes during the last glaciation (Laj et al., 1996; Voelker et al., 1998; Bard, 1998; Hughen et al., 2004; van der Plicht et al., 2004; Fairbanks et al., 2005) and different calibration models provide age estimates which can differ by more than $2 \mathrm{kyr}$.

Using the Fairbanks et al. (2005) calibration model for ages older than $20 \mathrm{kyr}{ }^{14} \mathrm{CBP}$, the obtained high-resolution local $\delta^{18} \mathrm{O}_{\text {sw }}$ record of core MD77-176 displays large millennial-scale oscillations over the period 40000 to 11000 yr BP (Fig. 3c). They suggest a correlation with the Greenland ice core record of changes in polar air temperature during the last glaciation. Such a correlation, if it exists, would be in good agreement with previous postulations of enhanced summer monsoon activity during D/O events (Wang et al., 2001; Burns et al., 2003). On that basis we therefore developed a second age model for core MD77176 , assuming that local $\delta^{18} \mathrm{O}_{\mathrm{sw}}$ changes in the northern 

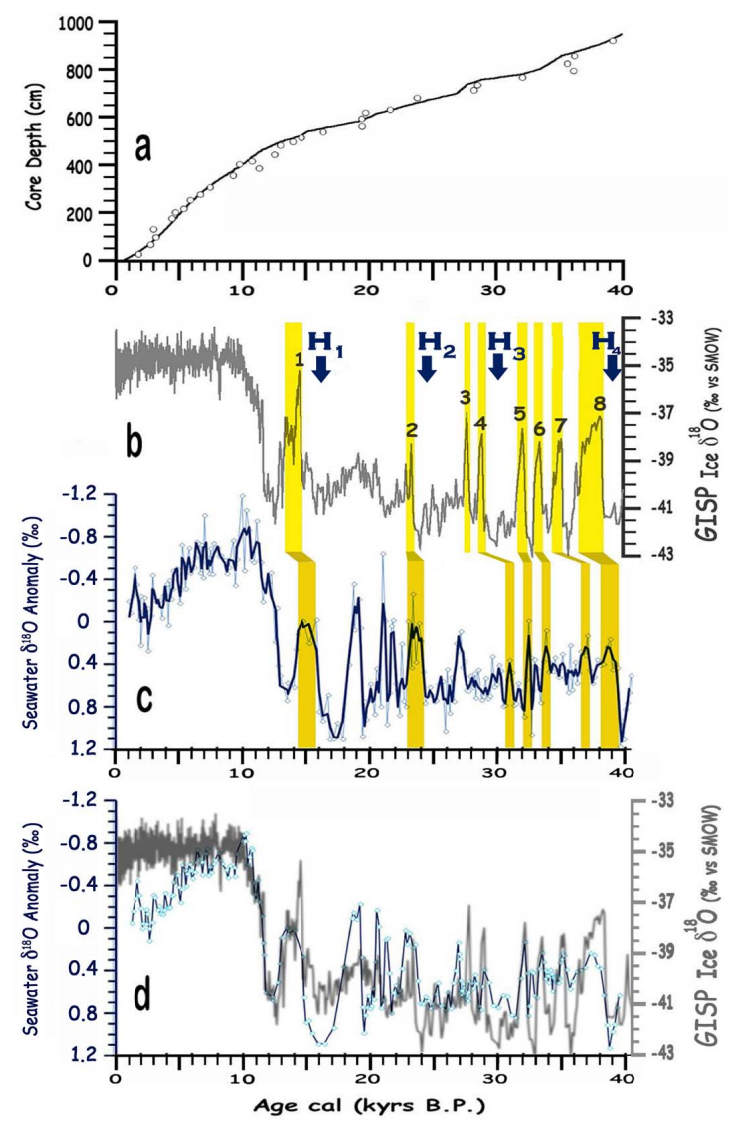

Fig. 3. (a) MD77-176 core depth versus age (circles represent ${ }^{14} \mathrm{C}$ ages converted into calendar ages using the Calib 4.1 program (Stuiver and Reimer, 1993; Stuiver et al., 1998) after $20 \mathrm{kyr}{ }^{14} \mathrm{C} \mathrm{BP}$ and the Fairbanks et al. (2005) calibration before. The line represents the age model developed assuming that changes in the northern Andaman Sea and GISP2 are in phase and synchronous); (b) Greenland ice core record GISP2: ice $\delta^{18} \mathrm{O}$ versus age; (c) MD77-176 core $\delta^{18} \mathrm{O}_{\mathrm{sw}}$ anomaly versus calendar age obtained using the Fairbanks et al. (2005) calibration. A smoothed curve obtained using 5-point moving-average is also shown. Coloured areas indicate correlations that we made between the Greenland and northern Andaman Sea records assuming that climatic events are in phase and synchronous in the two regions; (d) Comparison between GISP2 ice $\delta^{18} \mathrm{O}$ and the smoothed $\delta^{18} \mathrm{O}_{\mathrm{sw}}$ anomaly curve of the core MD77176 , with the Bay of Bengal age model tuned on that of the GISP2 record.

Andaman Sea and Greenland $\delta^{18} \mathrm{O}$ are in phase and synchronous. Comparison of this new age model with the ages calibrated using the Fairbanks et al. (2005) model for ages older than $20{ }^{14} \mathrm{C}$ kyr BP indicates that our assumption is realistic (Fig. 3). Between 13 and 10.5 kyr BP, Fig. 3a displays a difference of about 1 to $1.5 \mathrm{kyr}$ between the age model based on calibrated ${ }^{14} \mathrm{C}$ ages and that obtained by correlation with the GISP $2 \delta^{18} \mathrm{O}$ record. During the Younger Dryas for instance, the calibrated ${ }^{14} \mathrm{C}$ age of the lowering of the Bay of Bengal $\delta^{18} \mathrm{O}_{\mathrm{sw}}$ is older than the age of the cool- ing of the North Atlantic Younger Dryas by 1 to $1.5 \mathrm{kyr}$. This age anomaly must be a local phenomenon because it is not observed in sediment records from sites which are protected from the direct influence of rivers outflow (Rashid et al., 2007). On the other hand, two foraminifer development seasons are found today in the Bay of Bengal. The highest foraminiferal fluxes recorded in sediment traps occur during the peak summer and winter monsoon seasons. G. ruber productivity is however reduced in the northern Bay of Bengal during the summer monsoon because of the strong decrease in surface salinity (Guptha et al., 1997). Continental runoff increases during summer when precipitation associated to the Indian monsoon is higher. It is reasonable to suppose that, in the northern Bay of Bengal, the G. ruber population developing during the winter monsoon is dominant over the one developing during the summer in the modern foraminiferal assemblages because of the reduced salinity in the northern Bay of Bengal during summer monsoon. In the past, we can assume that when salinity increased in the northern Bay of Bengal, the contribution of G. ruber developed during summer increases with respect to that of winter monsoon. During the generally dry glacial episodes, summer monsoon changes should therefore be recorded in the $\delta^{18} \mathrm{O}$ of $G$. ruber with a better sensitivity than during modern conditions. For these glacial periods, freshwater injection into the Bay of Bengal can be fully detected in the $\delta^{18} \mathrm{O}$ records of $G$. ruber.

\subsection{Results}

Core MD77-176 faithfully records the enhanced southwest monsoon rains over the Indian subcontinent at the beginning of the Holocene (Fontes et al., 1996; Gasse et al., 1996; Van Campo et al., 1996; Van Campo and Gasse, 1993; COHMAP Members, 1988). During the early Holocene to about $4 \mathrm{kyr} \mathrm{BP}$, the surface water $\delta^{18} \mathrm{O}\left(\delta^{18} \mathrm{O}_{\mathrm{sw}}\right)$ was lower than today by about 0.2 to $0.8 \%$ in the Bay of Bengal. Considering the $\delta^{18} \mathrm{O}_{\mathrm{sw}}$ /salinity slope in the Northern Indian Ocean (0.25 to 0.37\% ; Delaygue et al., 2001; Rostek et al., 1993; Singh et al., 2010), the corresponding surface salinity decrease is about 0.5 to $2.5 \%$.

During the glaciation, the local sea water $\delta^{18} \mathrm{O}$ record of core MD77-176 displays many periods during which the freshwater input exhibits significant variations (Fig. 3c and d). The highest $\delta^{18} \mathrm{O}_{\text {sw }}$ were reached during the LGM. From 40 to $28 \mathrm{kyr} \mathrm{BP}, \delta^{18} \mathrm{O}_{\mathrm{sw}}$ values were lower than those of the LGM but higher than today. These observations are in agreement with the loess deposit records in southern and southeastern Tibet and in western China (Porter and An, 1995; Xiao et al., 1995; Guo et al., 1996; Chen et al., 1997; An et al., 1991, 1993) and with the changes in the intensity of Somalian and Arabian upwelling (Sirocko et al., 1991; Zonneveld et al., 1997), which show that the Indian summer monsoon was generally weak during the glaciation and always weaker than today. 
The general trend described above is punctuated by large abrupt changes of millennial scale. During the LGM, three episodes of low surface salinity occur at about 23, 20.5 and $19 \mathrm{kyr}$ BP (Fig. 3d). Also, during the upper part of the Marine Isotope Stage 3, 5 events of salinity decrease are recorded in core MD77-176. They occurred at about 37.5, $35,33.5,32$ and $27 \mathrm{kyr}$ BP on the GISP2 timescale. Most of these low salinity episodes observed in the Andaman Sea have equivalent warm episodes in the Greenland ice record (interstadials). Hence, during Greenland interstadials, the Indian summer monsoon appears to have been stronger, resulting in significant rainfall over the Indian subcontinent.

Between the freshwater injection events into the Bay of Bengal, events of salinity increase reflecting weak monsoons are recorded. Four of them have also been detected in Chinese loess sequences (at around 39, 31, 24 and 16 kyr BP), and are characterized by lower continental weathering intensity and coarser grain size peaks in the loess records (Porter and An, 1995; Xiao et al., 1995; Guo et al., 1996; Chen et al., 1997). Our chronology indicates that the high salinity events in the Bay of Bengal, like the Chinese dry/cold episodes, could be synchronous with the last four North Atlantic Heinrich events. However, not all the periods of marked reduction in the continental runoff into the Bay of Bengal during the last $40000 \mathrm{yr}$ correlate with Heinrich events. Some of the other cold stadials of the Greenland ice records could also be associated with very dry conditions over Asia.

The record of core MD77-176 is therefore consistent with the oxygen isotope records from stalagmites from eastern China (Wang et al., 2001; Cosford et al., 2008) and the nitrogen isotope ratio variations recorded in Arabian Sea sediment (Altabet et al., 2002). These records are also directly linked to the monsoon intensity. In the original interpretation of the speleothem data from eastern China, Wang et al. (2001) explain that the $\delta^{18} \mathrm{O}$ values from these speleothems are controlled by the summer/winter precipitation ratio: the summer precipitation $\delta^{18} \mathrm{O}$ is about $10 \%$ o lower than that of winter. Warmer Greenland temperatures were found to correlate with periods of stronger summer precipitation and therefore more intense summer East Asian monsoon. Recently, Pausata et al. (2011) suggested that positive $\delta^{18} \mathrm{O}$ excursions in the Chinese speleothems during the last glaciation reflects variations in the $\delta^{18} \mathrm{O}$ value of moisture exported from the Indian Ocean rather than changes in the rainfall intensity of East Asian monsoon. According to their results, Chinese speleothem $\delta^{18} \mathrm{O}$ variability would then reflect changes in the intensity of Indian rather than East Asian monsoon precipitation. In the Arabian Sea, $\delta^{15} \mathrm{~N}$ and thus denitrification were found to be high during the warm phases of the Dansgaard-Oeschger events and low during the cold phases of these events. High $\delta^{15} \mathrm{~N}$ values are interpreted as an indication of higher primary productivity and higher denitrification in the Arabian Sea, which are largely the result of more active upwelling and thus stronger summer monsoon winds (Altabet et al., 2002). However, alternative mechanisms have been proposed to drive the observed changes in Arabian Sea biological productivity. For instance, D-O variability in the Arabian Sea records could also be controlled by changes in AMOC strength via its impact on the global nutrient distribution (Schmittner, 2005; Schmittner et al., 2007; Ziegler et al., 2010).

Our record confirms the glacial millennial-scale variability of the Indian monsoon from the point of view of its impact on the hydrological cycle over the Bay of Bengal and adjacent river basins. The available chronology constraints suggest that warming in the North Atlantic area coincides with active glacial Indian summer monsoon. Even within the LGM, which was not the coldest glacial period in the midlatitude North Atlantic (Duplessy et al., 1991), some short events of active summer monsoon occurred in southeastern Asia. A similar relative strengthening of the Indian monsoon during the LGM was also inferred from the Somali and Arabian Sea upwelling records (Zonneveld et al., 1997; Sirocko et al., 1991). Nevertheless, our data demonstrate that the periods of Indian summer monsoon intensification during the last glaciation were not characterized by precipitations as intense as those of the Holocene. Our data show that the hydrological cycle associated with the monsoon is highly sensitive and coupled with abrupt climatic variations over the North Atlantic area.

In the next section, we examine which mechanism could be connecting the North Atlantic/Greenland temperatures and the Indian monsoon. Indeed, while glacial vs. Holocene vs. present monsoon fluctuations have been analysed via numerical experiments, the teleconnection with the North Atlantic abrupt events in glacial times has not been extensively studied. We therefore focus on this aspect with the following model analysis.

\section{Modelling study of the Indian monsoon response to a freshwater hosing under glacial conditions}

\subsection{Model and experiments}

In order to better understand the mechanisms relating the rapid variations of monsoon activity seen in the record presented above and those recorded in the North Atlantic and Greenland area, we analyse two modelling experiments to evaluate the impact of a freshwater hosing experiment on the Indian monsoon under glacial conditions. The model used in the present study is the coupled ocean-atmosphere IPSL_CM4 model (Marti et al., 2010). The atmospheric component of this coupled model is LMDZ.3.3 (Hourdin et al., 2006), with resolution $96 \times 71 \times 19$ gridpoints in longitude $\times$ latitude $\times$ altitude. The horizontal grid is regular, while the vertical levels are more numerous near the surface. This atmospheric component is coupled with the land surface scheme ORCHIDEE (Krinner et al., 2005) which includes a river routing scheme for the 50 largest river basins in order 
to close the water budget between land and ocean (Ngo-Duc et al., 2005). The ocean component is ORCA2 (Madec et al., 1998), which uses an irregular horizontal grid of $182 \times 149$ points with a resolution of $2^{\circ}$, refined over key regions such as the North Atlantic and near the Equator. This model has 31 depth levels. The sea-ice component is the Louvain-laNeuve Ice Model (LIM2, Fichefet and Maqueda, 1997). The coupling of these components is performed using the OASIS (version 3) coupler (Valcke, 2006).

The glacial conditions are obtained by first simulating the LGM climate following the PMIP2 protocol: we use the ICE5G ice-sheet reconstruction (Peltier, 2004), atmospheric gas concentrations (Monnin et al., 2001; Dallenbach et al., 2000; Flückiger et al., 1999) and orbital parameters (Berger, 1978) for $21 \mathrm{kyr} \mathrm{BP}$. The river pathways are adapted for the LGM (Alkama et al., 2007). In glacial conditions, snow accumulates on the ice-sheets, which constitutes a sink in the global freshwater budget of the coupled system. The quantity of water in this sink is therefore distributed back to the ocean with a temporal averaging of $10 \mathrm{yr}$, in three wide latitude bands with limits at $40^{\circ} \mathrm{N}$ and $50^{\circ} \mathrm{S}$. This flux is termed "calving" as it is an attempt to represent a calving flux from the ice-sheets without using a proper ice-sheet model. This procedure is not enough to exactly close the freshwater balance because of a slightly non-conservative atmospheric convection scheme. In the control experiment, labeled LGMc (c for control), this imbalance is compensated by multiplying global precipitations by $2.1 \%$ over the oceans. This simulation presents an active AMOC (maximum overturning in the North Atlantic of $18 \mathrm{~Sv}$ ). In the second simulation, labeled LGMh (h for hosing), this correction in global precipitation is not applied but a freshwater flux is applied in the North Atlantic and Arctic oceans north of $40^{\circ} \mathrm{N}$. This freshwater flux is obtained by doubling the "calving" flux over the North Atlantic and Arctic oceans, which represents an additional $0.18 \mathrm{~Sv}$ freshwater input into the North Atlantic and Arctic Oceans. This results in a collapse of the AMOC, which reaches $2 \mathrm{~Sv}$ after $250 \mathrm{yr}$. This latter experiment is therefore a highly idealized simulation of a Heinrich event under glacial conditions. The climatologies presented in this study are computed over the years 201-250 for LGMc and 371-420 for LGMh. More details on the experimental set up and on the AMOC response to the freshwater input can be found in Kageyama et al. (2009), in which LGMc is labelled "LGMa" and LGMh is labelled "LGMc".

The evaluation of the IPSL_CM4 coupled model is presented in Marti et al. (2010). In present-day conditions, the model performs well in the tropical area. There is an underestimation of the amount of Indian monsoon rainfall over the land but the monsoon circulation is well depicted over the Indian Ocean. The model results for the mid-Holocene compare well with other models from the PMIP2 project (Braconnot et al., 2007). Using the same model, Marzin and Braconnot (2009) have shown that the Indian monsoon is sensitive to the precession changes between the early Holocene, the mid-Holocene and the preindustrial periods. These results indicate a gradual weakening of the Indian monsoon intensity throughout the Holocene and are consistent with the surface salinity evolution at the MD-77176 core site and with other records of past monsoon intensity. Regarding the LGM experiment, the Indian monsoon is not very sensitive to the LGM conditions compared to other PMIP2 models (Braconnot et al., 2007). This could be due to the fact that the AMOC is strong in this LGM control simulation and therefore it would correspond to a "warm" phase of a D/O event, with a monsoon not very different from today (Braconnot et al., 2007), and that the Indian monsoon is already weak in the control simulation. However, the hosing experiment presents a much weaker AMOC and can be considered as representative of a Heinrich event.

Finally, we test our mechanism for the relationship between the AMOC state and the Indian monsoon by using additional IPSL_CM4 coupled experiments run under the same LGM boundary conditions. The first experiment is the continuation of LGMh but with no freshwater hosing applied. In this simulation (in dark blue and labelled "LGM AMOC off" on Fig. 8) the AMOC never recovers. In the second experiment (in orange, labelled "-0.1 Sv") we have applied a negative freshwater flux in the North Atlantic between 50 and $70^{\circ} \mathrm{N}$ and as a result, the AMOC resumes after $350 \mathrm{yr}$ to an AMOC of $18 \mathrm{~Sv}$, i.e. equal to our reference state. This AMOC remains stable for another $70 \mathrm{yr}$, after which the simulation was stopped. The third set of experiments uses a stronger forcing of $-0.5 \mathrm{~Sv}$ over the same region, from three initial states of the AMOC off simulation, which were arbitrarily chosen $50 \mathrm{yr}$ apart. In all these experiments (in red and labelled " $-0.5 \mathrm{~Sv}$ ") the AMOC resumes in less than $100 \mathrm{yr}$ and reaches values larger than $20 \mathrm{~Sv}$. These simulations were not run to equilibrium. We use all the years from these simulations to test our teleconnection mechanism in Sect. 3.4.

\subsection{Indian monsoon weakening due to the collapse of the AMOC}

All results are shown for the season averaged from June to September (JJAS) to encompass the whole boreal summer monsoon season (Fig. 4). The main features discussed here are significant at the $95 \%$ level based on a Student's $t$ test but the significance is not shown on the figures for clarity. The freshwater input in the North Atlantic/Arctic region and the collapse of the AMOC between LGMh and LGMc results in a dipolar pattern of SST anomalies in the Atlantic, with a more than $3{ }^{\circ} \mathrm{C}$ cooling in the North Atlantic and a more than $1{ }^{\circ} \mathrm{C}$ warming in the South Atlantic (Fig. 4a). This typical cross-equatorial SST dipole is accompanied by a southward shift of the Intertropical Convergence Zone (ITCZ) over the Atlantic (Fig. 4b) that is consistent with previous studies (Stouffer et al., 2006; Timmermann et al., 2007; Wu and Kirtman, 2007; Chang et al., 2008) and with data (Peterson et al., 2000; Wang et al., 2004). Significant remote impacts 

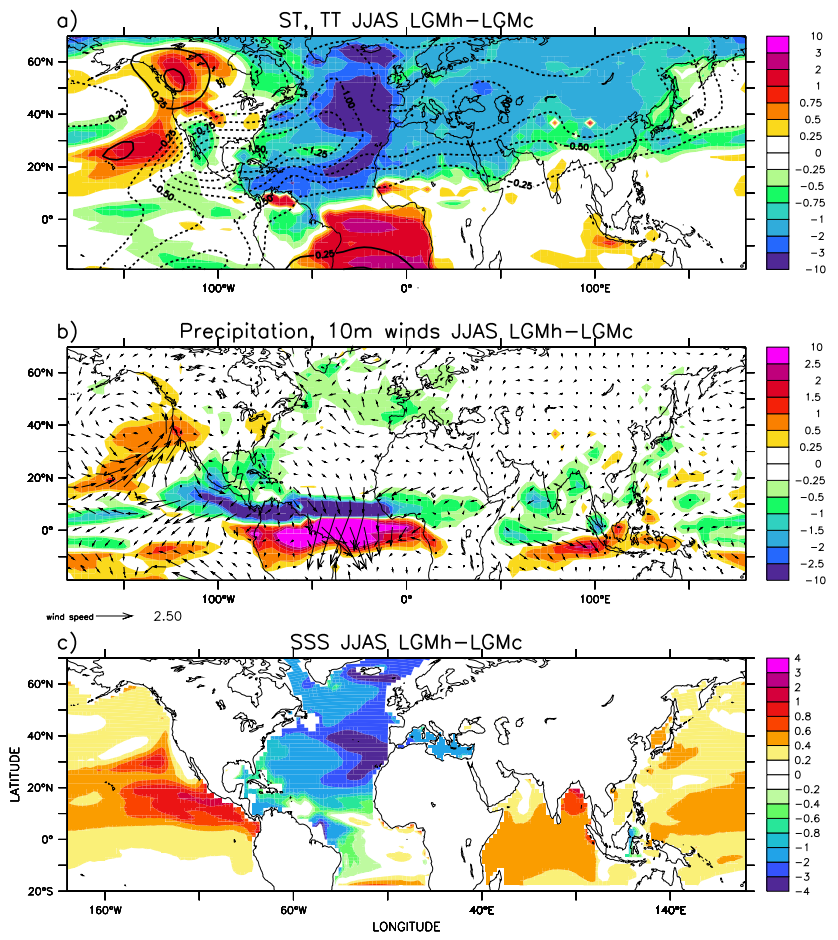

Fig. 4. Differences between LGMh and LGMc (hosing minus control experiment) of JJAS (June to September mean) (a) surface temperature (ST, shaded) and tropospheric temperature averaged from 200 to $500 \mathrm{hPa}$ (TT, contours), (b) precipitation and $10 \mathrm{~m}$ winds, (c) sea surface salinity (SSS).

are also seen across the globe, with, for example, the cooling of the North Atlantic extending across the whole Eurasian continent and the subtropical northwest Pacific. The North Atlantic forcing leads to significant precipitation and circulation changes in the Pacific Ocean. These features are further discussed in Kageyama et al. (2009) and are shown to be more pronounced in the case of the LGM than for other climatic periods (Swingedouw et al., 2009).

The North Atlantic hosing results in a statistically significant reduction of the Indian monsoon precipitation to the northeast and southwest of the subcontinent, by about $10 \%$ (Fig. 4b). The reduction in precipitation coincides with the core regions of simulated monsoon precipitation. The monsoon cross-equatorial flow is weakened over the Indian Ocean, therefore reducing the moisture advection into the monsoon region. This is consistent with the strong increase in precipitation on the southern side of the equator over the Indian Ocean. The strength of the southwesterly winds over the western Arabian Sea is reduced, which is consistent with records indicating changes in upwelling and productivity in this region coeval with North Atlantic changes (Schulz et al., 1998; Altabet et al., 2002; Gupta et al., 2003). The weakening of the Indian monsoon as a response to the freshwater input in the North Atlantic is consistent with other modelling studies discussed in the introduction, but our exper- iments confirm that this teleconnection holds under glacial conditions.

The reduction of the Indian monsoon intensity induces an increase in salinity over the whole Bay of Bengal (Fig. 4c). The amplitude of the anomalies ranges from 0.6 to $2 \%$ in the northern part of the Bay of Bengal, and is similar to the amplitude of the large variations in the northern Andaman Sea surface salinity record presented in Sect. 2.2. The freshwater content of the Bay of Bengal is under the influence of the fresh water input (precipitation minus evaporation and continental river runoff), as well as water transport from the south. This is reflected in the large variations of mixed layer thickness across the Bay of Bengal during the summer months (Varkey et al., 1996). The freshwater input is diagnosed from the model outputs and our hosing experiment shows that the river runoff in the north coastal region of the Bay of Bengal drops by $20 \%$ (by 0.02 to $0.06 \times 10^{-3} \mathrm{~kg} \mathrm{~m}^{-2} \mathrm{~s}^{-1}$ ) and the local freshwater input (precipitation minus evaporation) is also reduced over the whole Bay of Bengal by approximately $10 \%$ ( 0.006 to $\left.0.016 \times 10^{-3} \mathrm{~kg} \mathrm{~m}^{-2} \mathrm{~s}^{-1}\right)$ due to suppressed local precipitation over the ocean (Fig. 4a). Therefore, the model results show that the salinity changes in the Bay of Bengal highlighted in the northern Andaman Sea record as well as in the model outputs, are sensitive to the suppression of the hydrological cycle both over the land (reduction in river runoff) and over the ocean (reduction in local precipitation). As a result, this modelling study supports the hypothesis used for the age model of core MD77-176 which assumed that the local changes of the Andaman Sea are synchronous with the abrupt events of the Greenland ice core records.

The large-scale meridional gradient of upper tropospheric temperature (averaged from 200 to $500 \mathrm{hPa}$ ) over India has been shown to be an indicator of the monsoon seasonal evolution and intensity (He et al., 2003; Goswami and Xavier, 2005). This meridional gradient is considerably reduced in the hosing experiment (Fig. 4a) due to the upper tropospheric cooling anomaly over most of Eurasia. This reduction in the upper tropospheric temperature gradient is a direct indicator of the monsoon weakening. In Kageyama et al. (2009), the JJAS tropospheric temperature and the JJAS Indian monsoon rainfall are shown to decrease synchronously with the strength of the AMOC throughout the simulation. It has therefore been hypothesized that the predominant pathway from the North Atlantic perturbation to the Indian monsoon could be through the atmospheric circulation, which could be responsible for the large cooling of tropospheric temperature over the Eurasian continent, by the eastward advection of the North Atlantic cooling response.

The underlying mechanisms of this North Atlantic/Indian monsoon teleconnection are still being investigated by the community. In order to refine these analyses and to better understand the teleconnection mechanisms, we have performed the sensitivity experiments presented in the following 
section. These are also designed to test some of the hypotheses presented in the introduction.

\subsection{Sensitivity experiments and the dominant role of the tropical Atlantic}

To differentiate the impact of SST changes of several key regions on the Indian monsoon, we have performed three sensitivity experiments using the atmospheric component of the coupled model. The SST fields from the coupled experiments were used to force the atmospheric model and we tested the impact of SST changes due to the freshwater forcing in specific regions: the North Atlantic, the Tropical Atlantic, and, for completeness, all regions except the North and Tropical Atlantic. To do this, we applied the SSTs from the hosing experiment LGMh over the test region and the SSTs of the control experiment LGMc for the rest of the globe. In addition, to make sure that the atmospheric model replicates the results discussed above, we performed the atmosphere-only version of the control and the hosing experiments using the SSTs obtained from the coupled experiments over the whole globe (LGMcF and LGMhF). All the experiments are run for $50 \mathrm{yr}$ using continuous time series of $50 \mathrm{yr}$ of SSTs computed by the coupled model, in the simulations analysed in Sect. 3.2. The SST fields have monthly frequency so that the interannual variability of the coupled experiments is passed on to the forced experiments. The forced experiments are the following:

- LGMcF: simulation forced by the SST/sea-ice fields from the LGMc coupled control experiment over the whole globe.

- LGMhF: simulation forced by the SST/sea-ice fields from the LGMh coupled hosing experiment over the whole globe.

- LGMhNA: simulation forced by the SST/sea-ice fields from the LGMh simulation over the North Atlantic/Arctic region only (north of $30^{\circ} \mathrm{N}$ ) and by the LGMc SST/sea-ice fields elsewhere, to analyse the impact of the North Atlantic cooling (Fig. 5b).

- LGMhTA: simulation forced by the SST fields from the LGMh simulation over the tropical Atlantic region only $\left(30^{\circ} \mathrm{S}\right.$ to $\left.30^{\circ} \mathrm{N}\right)$ and by the LGMc SST/sea-ice fields elsewhere, to analyse the impact of the large dipolar SST anomaly (Fig. 5c).

- LGMhNTAC: complementary simulation of LGMhNA and LGMhTA, forced by the SST/seaice fields from the LGMh simulation over all the oceans except the North Atlantic/Arctic and tropical Atlantic regions for which the SSTs from the LGMc are used, to analyse the impact of the SST changes over the Indian and Pacific Oceans (Fig. 5d).
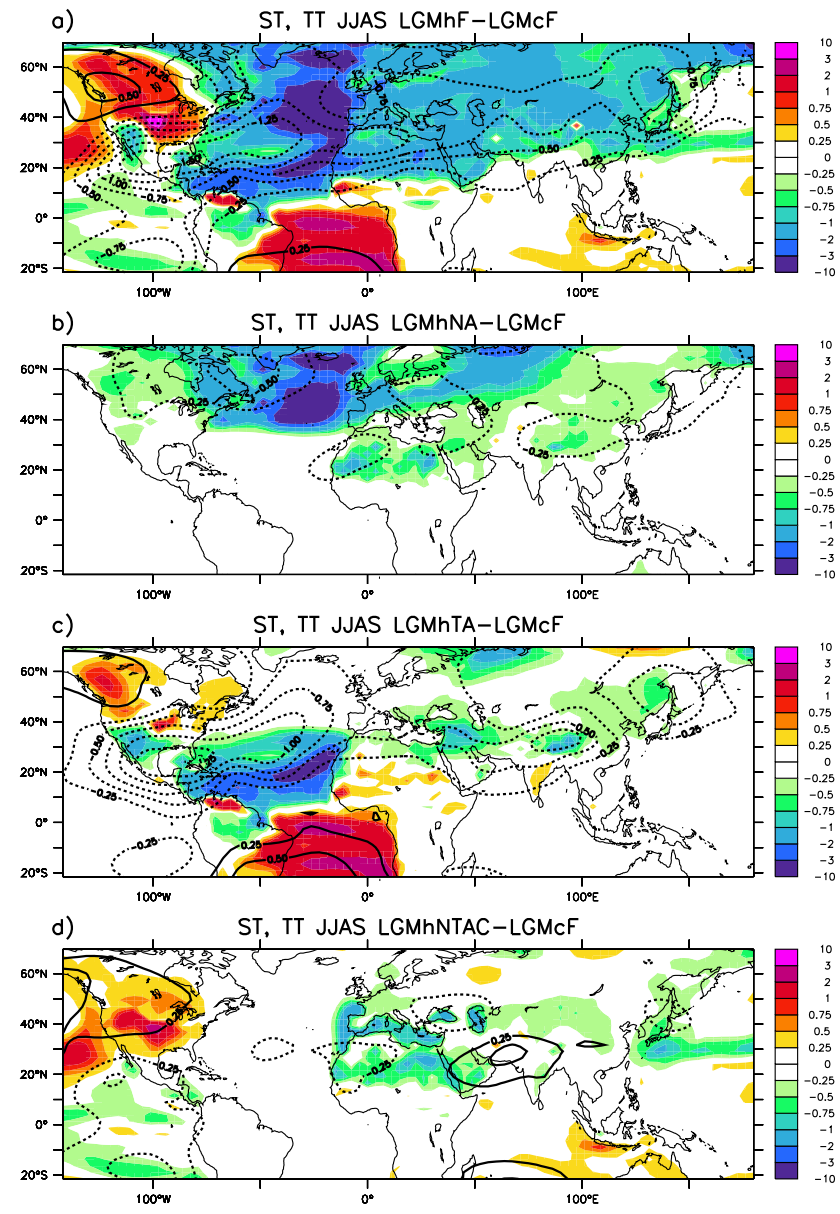

Fig. 5. Differences of JJAS surface temperature (ST, shaded) and tropospheric temperature averaged from 200 to $500 \mathrm{hPa}$ (TT, contours) between (a) LGMhF and LGMcF (hosing minus control experiment), (b) LGMhNA and LGMcF (North Atlantic minus control experiment), (c) LGMhTA and LGMcF (tropical Atlantic minus control experiment), (d) LGMhNTAC and LGMcF (complementary minus control experiment).

The results of these sensitivity experiments are presented in terms of surface and upper tropospheric temperature change (Fig. 5), precipitation and low level circulation change (Fig. 6), and $200 \mathrm{hPa}$ geopotential and circulation change (Fig. 7). The atmospheric model, forced by the SSTs from the previous coupled experiments, is able to reproduce the precipitation results presented in Sect. 3.2 both in terms of precipitation change over the Indian region (Fig. 6a) and of upper tropospheric cooling over Eurasia (Fig. 5a). The first sensitivity experiment indicates that the North Atlantic cooling only has a marginal impact on precipitation over the Indian region (Fig. 6b). Hence, our results demonstrate that the North Atlantic cooling associated with the freshwater input alone is not sufficient to explain the monsoon weakening. Even though the cooling over Eurasia is significant, the upper 

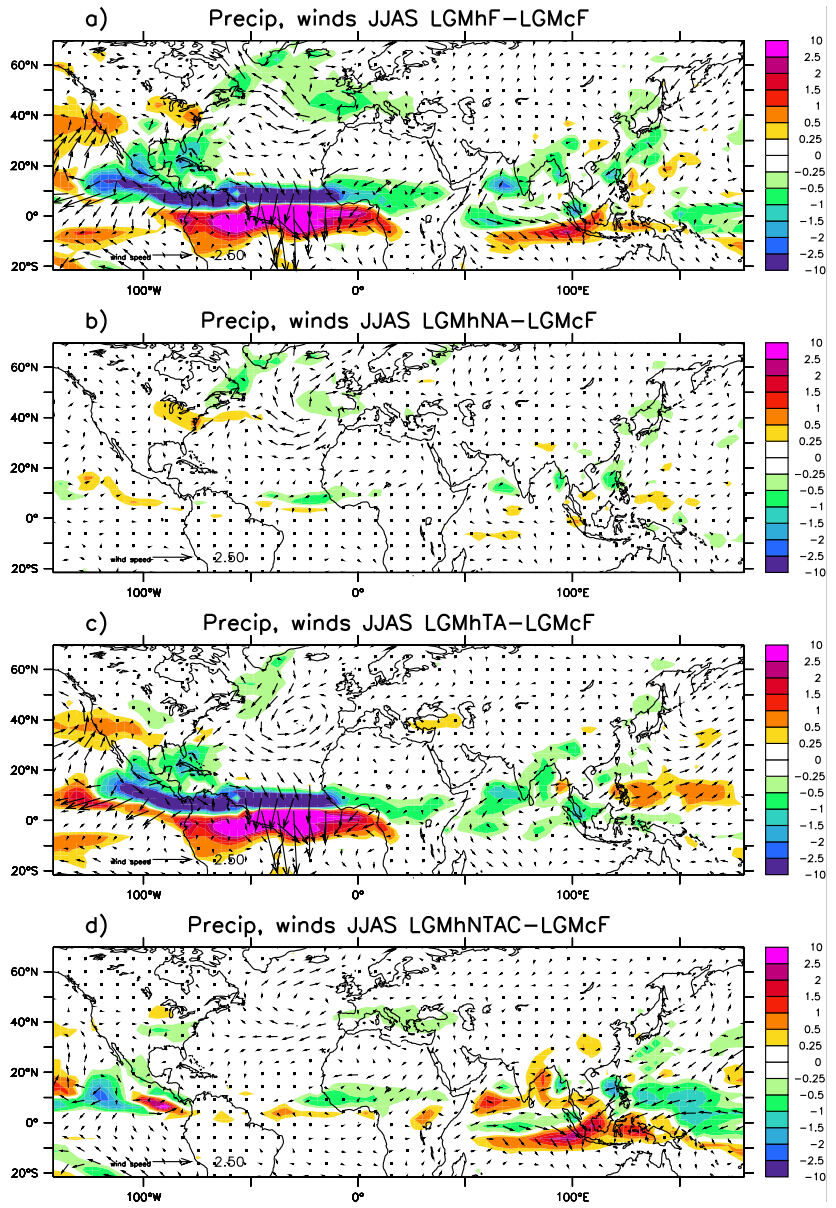

Fig. 6. Differences of JJAS precipitation and $10 \mathrm{~m}$ winds between (a) LGMhF and LGMcF, (b) LGMhNA and LGMcF, (c) LGMhTA and LGMcF, (d) LGMhNTAC and LGMcF.

tropospheric temperature (TT) is decreased by only $0.25^{\circ} \mathrm{C}$ over the Tibetan Plateau (Fig. 5b).

If the SST perturbation over the tropical Atlantic only is imposed (Fig. 5c), then the precipitation decrease seen in the coupled simulations over the southwest and northeast of India is fully recovered (Fig. 6c). The fact that the sole bipolar SST structure across the equatorial Atlantic is able to trigger such a response over the Indian region is remarkable. The TT signature over the Tibetan Plateau in this sensitivity experiment is larger than in LGMhNA, even though the decrease in surface temperatures does not extend as much over Eurasia (Fig. 5c). The weakening of the Indian monsoon intensity is associated with the reduction of the meridional gradient of upper tropospheric temperature in a consistent way with previous studies (Goswami et al., 2006; Lu and Dong, 2008). However, these studies suggest that the North Atlantic temperature changes directly impact the Eurasian continent, but we show that in our case it is more directly influenced by the tropical Atlantic bipolar SST anomaly and the associated southward shift of the ITCZ.

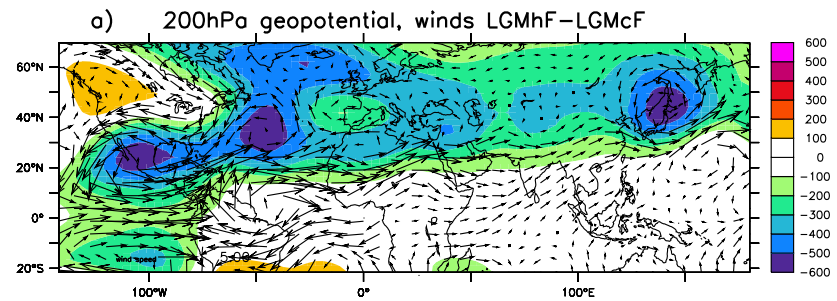

b) $200 \mathrm{hPa}$ geopotential, winds LGMhNA-LGMcF

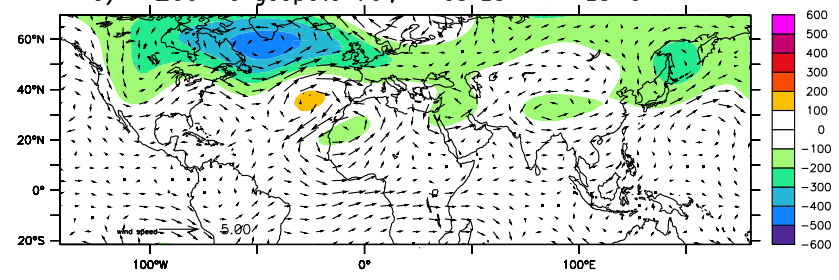

c) $200 \mathrm{hPa}$ geopotential, winds LGMhTA-LGMcF

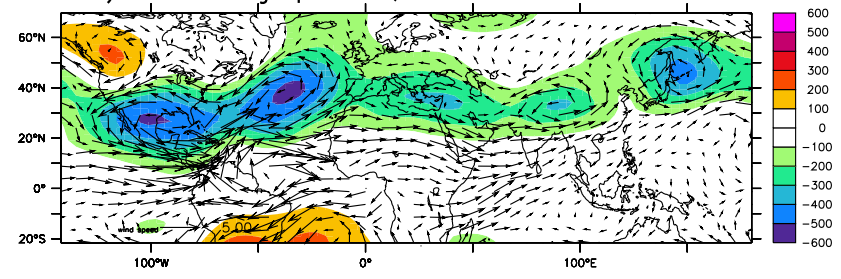

d) $200 \mathrm{hPo}$ geopotential, winds LGMhNTAC-LGMcF

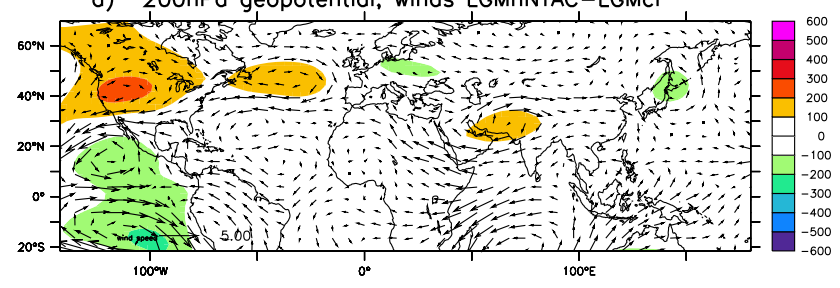

Fig. 7. Differences of JJAS $200 \mathrm{hPa}$ geopotential and winds between (a) LGMhF and LGMcF, (b) LGMhNA and LGMcF, (c) LGMhTA and $\mathrm{LGMcF}$, (d) LGMhNTAC and LGMcF.

In addition to this hypothesis of predominant link between the North Atlantic and the Indian monsoon through Eurasian continent, Zhang and Delworth (2005) and Lu and Dong (2008) suggest that the Indian monsoon is mostly influenced by changes in the tropical Pacific in their coupled experiments. Indeed, several studies show that the Atlantic perturbation is propagated to the Pacific through the Central American region (Dong and Sutton, 2002; Zhang and Delworth, 2005). Here, to isolate the impact of the Pacific Ocean and Indian Ocean SST changes in our modelling experiments, we have performed the complementary simulation LGMhNTAC. The cooling over the tropical eastern Pacific and the northeastern Pacific warming (Fig. 5d) is consistent with the above studies. The warming over the southern equatorial Indian Ocean is associated with an amplification of convective rainfall (Figs. 5d and 6d), and a large anomaly of reduced precipitation appears over the subtropical western Pacific. More strikingly, this sensitivity experiment shows that the SST changes in the Pacific and Indian Oceans actually amplify the monsoon rainfall over the western part of 
the Bay of Bengal and the eastern part of India (Fig. 6d). This is associated with a positive anomaly of upper tropospheric temperature over the north-west of India. This is consistent with the fact that the interannual variability of the Indian monsoon has been shown to be very sensitive to the upper tropospheric warming over this region (Xavier et al., 2007).

In summary, the North Atlantic SST changes cannot, on their own, directly produce a dampening of the monsoon activity. The Pacific and Indian SST changes related to the AMOC weakening actually result in an amplification of the Indian monsoon in our simulations. On the other hand, the tropical Atlantic SST changes due to the AMOC weakening proves to be the predominant factor explaining to be the weakening of the Indian monsoon. This bipolar SST anomaly is obtained both through atmospheric and oceanic pathways (Kageyama et al., 2009; Swingedouw et al., 2009), and we show with the atmosphere-only experiment LGMhTA that this anomaly is resulting in a weakening of the Indian monsoon through the cooling over the southern Eurasian continent.

The tropical Atlantic SST anomaly induces perturbations of the stationary waves in the northern extratropics (Fig. 7c), also seen in the TT (Fig. 5c). The wavetrain perturbations are propagated downstream from the North Atlantic to Eurasia, as seen from the negative anomalies of $200 \mathrm{hPa}$ geopotential. The LGMhTA simulation is the only one among our set of sensitivity experiments which reproduces the cyclonic anomalies of $200 \mathrm{hPa}$ winds and the acceleration of the subtropical westerly jet stream obtained in LGMhF over the Atlantic and downstream (Fig. 7a). These are the signatures of a southward shift of the subtropical jet stream over these regions. Hence in our experiments the connection between the subtropical Atlantic surface temperatures and the Indian monsoon appears to be operating via the subtropical jet stream wave guide, as proposed by Ding and Wang (2005, 2007). The southward shift of the jet stream is consistent with the SST anomaly which is negative in the northern tropical Atlantic and positive in the southern tropical Atlantic, for several reasons: (1) the northern tropical cooling implies a southward shift of the meridional SST gradient, and hence of the jet stream, via the thermal wind relationship; (2) the southward position of the ITCZ, which is itself a result of the AMOC decrease (cf. Kageyama et al., 2009; Swingedouw et al., 2009) and of the convection taking place over the warmest areas, is associated with a southward shift of the whole Hadley cell and therefore of subtropical jet stream. As discussed in the introduction, Kucharski et al. (2009) showed that the Indian monsoon could also be sensitive to the positive SST anomaly in the south tropical Atlantic through a dynamical response to the increased convection activity over this region. In LGMhTA, this does not appear to be the case: the response in terms of the $200 \mathrm{hPa}$ eddy streamfunction is strong over the Atlantic but the two eastern poles of the GillMatsuno theoretical response over the eastern Indian Ocean are weak (not shown). However, it would be interesting to distinguish between the role of the northern tropical Atlantic cooling vs. that of the southern tropical Atlantic warming to further examine this question.

Following the comment by Clement and Peterson (2008) that the contribution of the land surface snow cover and sensible heating over the Tibetan Plateau has not been investigated, we have verified that the Indian monsoon weakening is not driven by changes in the snow cover over the Tibetan Plateau as these are marginal in our experiments (not shown). The large-scale deep upper tropospheric cooling over the Tibetan Plateau induced by the collapse of the AMOC is the main factor explaining the weakening of the Indian monsoon, as suggested by Goswami et al. (2006) in their study of the links between the Atlantic Multidecadal Oscillation and the strength of the Indian monsoon. Here we show that this is more effectively caused by the tropical Atlantic influence than by the North Atlantic cooling itself, the anomaly over the tropical Atlantic triggering a southward shift of the subtropical jet stream, which acts to decrease the upper tropospheric temperatures over the key area of the Tibetan Plateau and finally the Indian monsoon.

\subsection{Testing the tropical teleconnection mechanisms in additional experiments in which the AMOC resumes}

In this section, our objective is to test if the connection between the tropical SST changes and Indian monsoon precipitation is found in other coupled experiments in which the AMOC is forced to vary and if it is valid during the transitions between the different AMOC states which we have studied via our sensitivity experiments. We also want to examine if the pathway of the connection, via the upper-level subtropical jet stream, is still valid.

Figure 8 shows results from all years of all the simulations (each year represented by a dot). The top left figure confirms the relationship between the intensity of the Indian monsoon and the strength of the Atlantic ocean heat transport: the lower the transport, the weaker the Indian monsoon (the ocean heat transport plotted on Fig. 8 is the maximum of the total northward heat transport by the Atlantic Ocean between the equator and $25^{\circ} \mathrm{N}$ ). This relationship is broken down in different steps of the teleconnection pathway in the remaining three panels of this figure. On the top right panel, we use the $200 \mathrm{hPa}$ zonal wind strength over the Sahara as a measure of the southward position of the subtropical jet stream: the stronger the wind strength over this region, the more the subtropical jet stream is located to the south over Africa. This panel shows that the stronger the jet stream over the Sahara, the weaker the Indian monsoon. The lower left panel shows that this wind strength is larger for cooler North Atlantic SSTs (and for warmer South Atlantic SSTs, not shown). Finally, these North Atlantic SSTs are positively correlated with the Atlantic ocean heat transport. Thus, the pathway found thanks to our sensitivity experiments is confirmed 

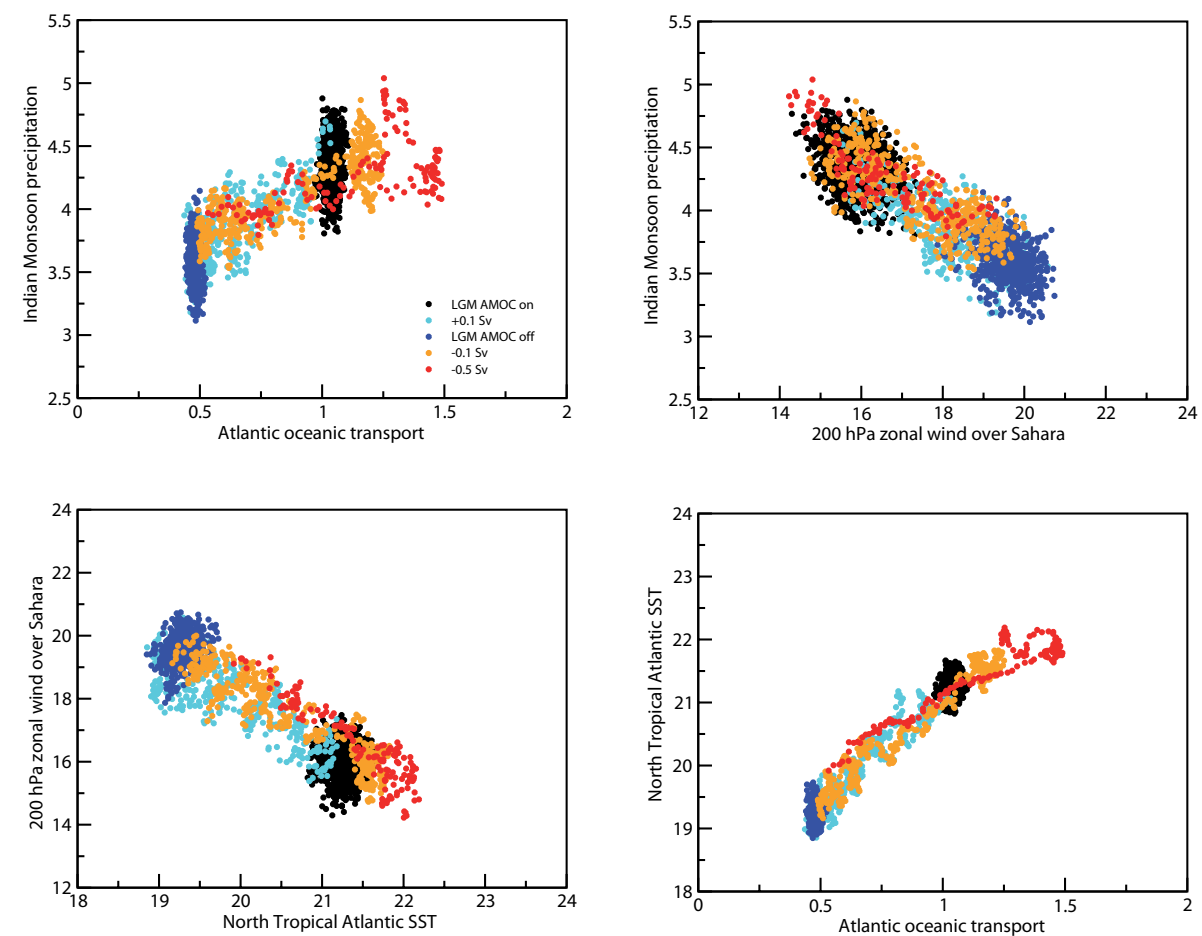

Fig. 8. (a) Yearly JJAS values of Indian monsoon precipitation $\left(\mathrm{mm} \mathrm{day}^{-1}\right)$ over the region $\left(60-80^{\circ} \mathrm{E}, 5-15^{\circ} \mathrm{N}\right)$ vs. total Atlantic oceanic northward heat transport maximum (in PW, with the maximum being searched between the equator and $25^{\circ} \mathrm{N}$ ), (b) Indian monsoon precipitation $\left(\mathrm{mm} \mathrm{day}^{-1}\right)$ vs. $200 \mathrm{hPa}$ zonal wind $\left(\mathrm{m} \mathrm{s}^{-1}\right)$ over the Sahara $\left(15^{\circ} \mathrm{W}-45^{\circ} \mathrm{E}, 10-30^{\circ} \mathrm{N}\right)$, (c) $200 \mathrm{hPa}$ zonal wind over the Sahara vs. northern tropical Atlantic SST $\left({ }^{\circ} \mathrm{C}\right)$ over the region $\left(45-15^{\circ} \mathrm{W}, 10-30^{\circ} \mathrm{N}\right)$ and (d) northern tropical Atlantic SST vs. total Atlantic oceanic heat transport.

by the complementary analysis of our coupled experiments in which the AMOC is forced to collapse and then to resume at different speeds. This shows that this pathway can act fast, even at interannual/decadal timescales.

\section{Conclusions}

In this study, we attempt to give a new characterization of the Indian monsoon abrupt changes during the last glacial period by showing the results from a core from the northern Andaman Sea and to understand those changes through dedicated modelling experiments. The Andaman Sea highresolution record covers the period of the last $40000 \mathrm{yr}$ and shows very large salinity variations in the Bay of Bengal, which are interpreted as Indian monsoon fluctuations that have an impact on the hydrology of the Bay of Bengal. As expected, Indian monsoon precipitation is strongest during the first half of the Holocene and weaker than present during glacial times. The aspect on which we focus in this study is the millennial-scale variability of the Indian monsoon during the last glacial. This variability is of large amplitude, although the periods of Indian summer monsoon intensification during the last glaciation were not characterized by precipitation as intense as those of the Holocene in this dataset.
The available chronological constraints are consistent with the following relationship: warming (resp. cooling) in the North Atlantic area and in the Greenland ice core record of changes in polar air temperature coincides with active (resp. weakened) glacial Indian summer monsoon circulation.

A freshwater hosing numerical experiment under glacial conditions is set up to test the interpretation of the paleoclimatic record as reflecting Indian monsoon variations and to analyse the mechanisms of teleconnection between abrupt climate changes in Greenland and the North Atlantic and hydrological changes in the Bay of Bengal. In this simulation, the North Atlantic cools and the Indian monsoon rainfall and circulation weakens. The increase in salinity in the Bay of Bengal is due to a decrease in continental runoff and in precipitation minus evaporation over the ocean. The monsoon weakening is associated with an upper tropospheric temperature cooling over the Tibetan Plateau.

Sensitivity experiments to local SST changes are realised to test the teleconnection mechanism with the Indian monsoon. These sensitivity tests show that in the present case of a glacial background state, previously suggested mechanisms like the direct influence of the North Atlantic SST changes on the Indian monsoon and the ocean-atmosphere interactions in the Pacific are not sufficient to explain the changes 
obtained for the Indian monsoon in our model. It is the dipole of SST anomalies obtained in the tropical Atlantic Ocean that impacts the most the Indian monsoon. These anomalies excite a wave train perturbation across Africa and the Eurasian continent, which is characterised by a southward shift of the subtropical westerly jet. The centre of perturbation around the Tibetan Plateau directly affects the intensity of the monsoon through the reduction of the meridional upper tropospheric temperature gradient over India. This is reminiscent of the results reported by Ding and Wang (2005) and Ding and Wang (2007) for present-day, rather than the connection to the south tropical Atlantic temperatures proposed by Kucharski et al. (2009). A study of the impacts of the northern tropical Atlantic cooling and of the southern tropical Atlantic warming examined separately would help to further study the role of each of these mechanisms.

We designed our numerical experiments looking for a mechanism connecting the North Atlantic abrupt events and the fluctuations of the Indian monsoon during the last glacial. Our sensitivity experiments finally show that the tropical Atlantic plays an important role in transmitting the perturbation between these two remote areas. In a more general context, the tropical Atlantic surface temperatures could be perturbed by other mechanisms and our findings do not exclude a role for southern extra-tropical temperature variations, as suggested by Rohling et al. (2009) and Caley et al (2013). Further coupled experiments in which these latitudes are perturbed would be needed to study this role.

A possible limitation of the modelling results is a bias in the representation of the Indian monsoon intensity and a bias in the westerly jet position that is too far south in our model (Marti et al., 2010). However, despite different previous freshwater hosing experiments showing different results in SST and precipitation over the Pacific and the Indian Ocean, the SST and precipitation anomalies over the tropical Atlantic and the weakening of the Indian monsoon are always a common feature (Kageyama et al., 2013). It would therefore be interesting to examine whether the mechanism suggested here is robust in other models. A detailed comparative analysis of hosing experiments, including sensitivity tests with several models would be of immense benefit to get more insight in this teleconnection. The validity of this mechanism could also be tested with other models and under different climatic conditions, following the rationale of Swingedouw et al. (2009), who analyse the impact of freshwater hosing experiments for the present, the future, the Holocene, the LGM and the Eemian.

Our data/model comparison is successful in providing the bigger picture behind the Bay of Bengal hydrological cycle changes. However, the fact that not all the low salinity events in the record are correlated with Heinrich events indicates that the complex variability of the tropics during the last glaciation and its interaction with higher latitudes are not yet fully understood, and some studies suggest that the tropics and high latitudes interactions should be approached as a more global and coupled feedback in order to explain the abrupt climate changes that happened around the globe (Tierney and Russell, 2007; Seager and Battisti, 2007; Clement and Peterson, 2008). Also, similar detailed analysis of teleconnection mechanisms between North Atlantic climate change and other monsoon systems should be carried out as each system could respond in a very different way.

Acknowledgements. We thank the four reviewers and the editor for their comments which were very useful to improve the presentation of our results. LSCE scientists are supported by CNRS-INSU and CEA. Core MD77-176 has been raised during the 1977 cruise of the R/V Marion Dufresne, supported by TAAF (Terres australes et antractiques françaises) and IPEV (Institut Paul-Emile Victor). All simulations were run at the CEA/CCRT computing centre, which we acknowledge for the computing and storage facilities. We also wish to thank Ramdane Alkama who ran the first freshwater hosing experiment with the IPSL model under glacial conditions "just as a try". N. Kallel gratefully acknowledges LSCE, University of Sfax, "Ministère Tunisien de l'Enseignement Supérieur" and "l'Institut Français de Coopération à Tunis" (projets CMCU). M. Kageyama thanks the organisers and participants of the 2012 ESF conference on "Modes of Variability in the Climate System: Past-Present-Future" for their encouraging comments.

\section{Edited by: T. Kiefer}

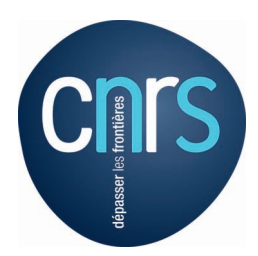

The publication of this article is financed by CNRS-INSU.

\section{References}

Allen, J. R. M., Brandt, U., Brauer, A., Hubberten, H. W., Huntley, B., Keller, J., Kraml, M., Mackensen, A., Mingram, J., Negendank, J. F. W., Nowaczyk, N. R., Oberhansli, H., Watts, W. A., Wulf, S., and Zolitschka, B.: Rapid environmental changes in southern Europe during the last glacial period, Nature, 400, 740743, 1999.

Altabet, M. A., Higginson, M. J., and Murray, D. W.: The effect of millennial-scale changes in Arabian Sea denitrification on atmospheric $\mathrm{CO}_{2}$, Nature, 415, 159-162, 2002.

An, Z. S., Wu, X. H., Wang, P. X., Wang, S. M., Dong, G. R., Sun, X. J., Zhang, D. E., Lu, Y. C., Zheng, S. H., and Zhao, S. L.: Paleomonsoons of China Over the Last 130,000 Years - Paleomonsoon Variation, Sci. China Ser. B, 34, 1016-1024, 1991.

An, Z. S., Porter, S. C., Zhou, W. J., Lu, Y. C., Donahue, D. J., Head, M. J., Wu, X. H., Ren, J. Z., and Zheng, H. B.: Episode of Strengthened Summer Monsoon Climate of Younger Dryas Age On the Loess Plateau of Central China, Quatern. Res., 39, 45-54, 1993.

Bard, E.: Geochemical and geophysical implications of the radiocarbon calibration, Geochim. Cosmochim. Acta, 62, 2025-2038, 1998. 
Barrows, T. and Juggins, S.: Sea-surface temperatures around the Australian margin and Indian Ocean during the Last Glacial Maximum, Quaternary Sci. Rev., 24, 1017-1047, 2005.

Behl, R. J. and Kennett, J. P.: Brief interstadial events in the Santa Barbara basin, NE Pacific, during the past $60 \mathrm{kyr}$, Nature, 379, 243-246, 1996.

Berger, A. L.: Long-Term Variations Of Daily Insolation And Quaternary Clim. Changes, J. Atmos. Sci., 35, 2362-2367, 1978.

Bond, G., Heinrich, H., Broecker, W., Labeyrie, L., McManus, J., Andrews, J., Huon, S., Jantschik, R., Clasen, S., Simet, C., Tedesco, K., Klas, M., Bonani, G., and Ivy, S.: Evidence for massive discharges of icebergs into the North Atlantic Ocean during the last glacial period, Nature, 360, 245-249, 1992.

Braconnot, P., Otto-Bliesner, B., Harrison, S., Joussaume, S., Peterchmitt, J.-Y., Abe-Ouchi, A., Crucifix, M., Driesschaert, E., Fichefet, Th., Hewitt, C. D., Kageyama, M., Kitoh, A., Laîné, A., Loutre, M.-F., Marti, O., Merkel, U., Ramstein, G., Valdes, P., Weber, S. L., Yu, Y., and Zhao, Y.: Results of PMIP2 coupled simulations of the Mid-Holocene and Last Glacial Maximum Part 1: experiments and large-scale features, Clim. Past, 3, 261277, doi:10.5194/cp-3-261-2007, 2007.

Broecker, W. S. and Peng, T.-H.: Tracers in the Sea, LamontDoherty Geological Observatory, Palisades, NY, 1982.

Broecker, W. S., Bond, G., Klas, M., Clark, E., and McManus, J.: Origin of the northern Atlantic's Heinrich events, Clim. Dynam., 6, 265-273, 1992.

Burns, S. J., Fleitmann, D., Matter, A., Kramers, J., and Al-Subbary, A. A.: Indian Ocean climate and an absolute chronology over Dansgaard/Oeschger events 9 to 13, Science, 301, 1365-1367, 2003.

Caley, T., Malaizé, B., Kageyama, M., Landais, A., and MassonDelmotte, V.: Bi-hemispheric forcing for Indo-Asian monsoon during glacial terminations, Quaternary Sci. Rev., 59, 1-4, 2013.

Chang, P., Zhang, R., Hazeleger, W., Wen, C., Wan, X. Q., Ji, L., Haarsma, R. J., Breugem, W. P., and Seidel, H.: Oceanic link between abrupt changes in the North Atlantic Ocean and the African monsoon, Nat. Geosci., 1, 444-448, 2008.

Chen, F., Bloemendal, J., Wang, J., Li, J., Oldfield, F., and Ma, H.: High-resolution multi-proxy climate records from Chinese loess: evidence for rapid climatic changes between $70 \mathrm{ka}$ and $10 \mathrm{ka}, \mathrm{Pa}-$ leogeogr. Paleocl., 130, 323-335, 1997.

Clement, A. C. and Peterson, L. C.: Mechanisms of abrupt climate change of the last glacial period, Rev. Geophys., 46, RG4002, doi:10.1029/2006RG000204, 2008.

COHMAP Members: Clim. Changes of the Last 18,000 Years: Observations and Model Simulations, Science, 241, 1043-1052, 1988.

Cosford, J., Qing, H. R., Yuan, D. X., Zhang, M. L., Holmden, C., Patterson, W., and Hai, C.: Millennial-scale variability in the Asian monsoon: Evidence from oxygen isotope records from stalagmites in Southeastern China, Palaeogeogr. Palaeocl., 266, $3-$ $12,2008$.

Craig, H. and Gordon, L. I.: Deuterium and oxygen 18 variations in the ocean and the marine atmosphere, Marine Geochemistry, Narragansett Marine Laboratory, University of Rhode Island, 3, 277-374, 1965 .

Cullen, J. L.: Microfossil Evidence For Changing Salinity Patterns In the Bay of Bengal Over the Last 20000 Years, Palaeogeogr. Palaeocl., 35, 315-356, 1981.
Dallenbach, A., Blunier, T., Fluckiger, J., Stauffer, B., Chappellaz, J., and Raynaud, D.: Changes in the atmospheric $\mathrm{CH}_{4}$ gradient between Greenland and Antarctica during the Last Glacial and the transition to the Holocene, Geophys. Res. Lett., 27, 10051008, 2000.

Dansgaard, W., Johnsen, S. J., Clausen, H. B., Dahljensen, D., Gundestrup, N. S., Hammer, C. U., Hvidberg, C. S., Steffensen, J. P., Sveinbjornsdottir, A. E., Jouzel, J., and Bond, G.: Evidence For General Instability Of Past Climate From A 250-Kyr Ice-Core Record, Nature, 364, 218-220, 1993.

Delaygue, G., Bard, E., Rollion, C., Jouzel, J., Stievenard, M., Duplessy, J. C., and Ganssen, G.: Oxygen isotope/salinity relationship in the northern Indian Ocean, J. Geophys. Res.-Oceans, 106, 4565-4574, 2001.

Ding, Q. H. and Wang, B.: Circtunglobal teleconnection in the Northern Hemisphere summer, J. Climate, 18, 3483-3505, 2005.

Ding, Q. H. and Wang, B.: Intraseasonal teleconnection between the summer Eurasian wave train and the Indian monsoon, J. Climate, 20, 3751-3767, 2007.

Dong, B. W. and Sutton, R. T.: Adjustment of the coupled ocean-atmosphere system to a sudden change in the Thermohaline Circulation, Geophys. Res. Lett., 29, 1728, doi:10.1029/2002GL015229, 2002.

Duplessy, J.-C.: Glacial to interglacial contrasts in the northern Indian Ocean, Nature, 295, 494-498, 1982.

Duplessy, J.-C., Labeyrie, L., Juillet-Leclerc, A., Maitre, F., Duprat, J., and Sarnthein, M.: Surface Salinity Reconstruction of the North Atlantic Ocean During the Last Glacial Maximum, Oceanol. Acta, 14, 311-324, 1991.

Elliot, M., Labeyrie, L., and Duplessy, J.-C.: Changes in North Atlantic deep-water formation associated with the DansgaardOeschger temperature oscillations (60-10 ka), Quaternary Sci Rev., 21, 1153-1165, 2002.

Emiliani, D.: Depth habitats of some species of pelagic foraminifera as indicated by oxygen isotope ratios, Am. J. Sci., 252, 149-158, 1954.

EPICA Community Members: One-to-one coupling of glacial climate variability in Greenland and Antarctica, Nature, 444, 195198, 2006.

Epstein, S. R., Buchsbaum, R., Lowenstam, H. A., and Urey, H. C.: Revised carbonate-water isotopic temperature scale, Geol. Soc. Am. Bull., 64, 1315-1325, 1953.

Fairbanks, R. G., Mortlock, R. A., Chiu, T. C., Cao, L., Kaplan, A., Guilderson, T. P., Fairbanks, T. W., Bloom, A. L., Grootes, P. M., and Nadeau, M. J.: Radiocarbon calibration curve spanning 0 to 50,000 years BP based on paired ${ }^{230} \mathrm{Th} /{ }^{234} \mathrm{U} /{ }^{238} \mathrm{U}$ and ${ }^{14} \mathrm{C}$ dates on pristine corals, Quaternary Sci. Rev., 24, 1781-1796, 2005.

Feng, S. and Hu, Q.: How the North Atlantic Multidecadal Oscillation may have influenced the Indian summer monsoon during the past two millennia, Geophys. Res. Lett., 35, L01707, doi:10.1029/2007GL032484, 2008.

Fichefet, T. and Maqueda, M. A. M.: Sensitivity of a global sea ice model to the treatment of ice thermodynamics and dynamics, J. Geophys. Res., 102, 12609-12646, 1997.

Flückiger, J., Dallenbach, A., Blunier, T., Stauffer, B., Stocker, T. F., Raynaud, D., and Barnola, J. M.: Variations in atmospheric $\mathrm{N}_{2} \mathrm{O}$ concentration during abrupt climatic changes, Science, 285, 227230, 1999. 
Fontes, J. C., Gasse, F., and Gibert, E.: Holocene environmental changes in Lake Bangong basin (western Tibet), 1. Chronology and stable isotopes of carbonates of a Holocene lacustrine core, Palaeogeogr. Palaeocl., 120, 25-47, 1996.

Gasse, F., Fontes, J. C., VanCampo, E., and Wei, K.: Holocene environmental changes in Bangong Co basin (western Tibet), 4. Discussion and conclusions, Palaeogeogr. Palaeocl., 120, 7992, 1996.

Goswami, B. N. and Xavier, P. K.: ENSO control on the south Asian monsoon through the length of the rainy season, Geophys. Res. Lett., 32, L18717, doi:10.1029/2005GL023216, 2005.

Goswami, B. N., Madhusoodanan, M. S., Neema, C. P., and Sengupta, D.: A physical mechanism for North Atlantic SST influence on the Indian summer monsoon, Geophys. Res. Lett., 33, L02706, doi:10.1029/2005GL024803, 2006.

Grootes, P. M., Stuiver, M., White, J. W. C., Johnsen, S., and Jouzel, J.: Comparison Of Oxygen-Isotope Records From The Gisp2 And Grip Greenland Ice Cores, Nature, 366, 552-554, 1993.

Guo, Z., Liu, T., Guiot, J., Wu, N., Lu, H., Han, J., Liu, J., and Gu, Z.: High frequency pulses of East Asian monsoon climate in the last two glaciations: Link with the North Atlantic, Clim. Dynam., 12, 701-709, 1996.

Gupta, A. K., Anderson, D. M., and Overpeck, J. T.: Abrupt changes in the Asian southwest monsoon during the Holocene and their links to the North Atlantic Ocean, Nature, 421, 354-357, 2003.

Guptha, M. V. S., Curry, W. B., Ittekkot, V., and Muralinath, A. S.: Seasonal variation in the flux of planktonic foraminifera: sediment trap results from the Bay of Bengal, Northern Indian Ocean, J. Foraminiferal Res., 27, 5-19, 1997.

He, H. Y., Sui, C. H., Jian, M. Q., Wen, Z. P., and Lan, G. D.: The evolution of tropospheric temperature field and its relationship with the onset of Asian summer monsoon, J. Meteorol. Soc. Jpn., 81, 1201-1223, 2003.

Heinrich, H.: Origin and consequences offset cyclic ice rafting in the northeast Atlantic Ocean during the past 130,000 years, Quatern. Res., 29, 142-152, 1988.

Hourdin, F., Musat, I., Bony, S., Braconnot, P., Codron, F., Dufresne, J. L., Fairhead, L., Filiberti, M. A., Friedlingstein, P., Grandpeix, J. Y., Krinner, G., Levan, P., Li, Z. X., and Lott, F.: The LMDZ4 general circulation model: climate performance and sensitivity to parametrized physics with emphasis on tropical convection, Clim. Dynam., 27, 787-813, 2006.

Hughen, K., Lehman, S., Southon, J., Overpeck, J., Marchal, O., Herring, C., and Turnbull, J.: ${ }^{14} \mathrm{C}$ activity and global carbon cycle changes over the past 50,000 years, Science, 303, 202-207, 2004.

Hutson, W.: The Agulhas Current during the Late Pleistocene: Analysis of modern faunal analogs, Science, 207, 64-66, 1979.

Jin, L., Chen, F., Ganopolski, A., and Claussen, M.: Response of East Asian climate to Dansgaard/Oeschger and Heinrich events in a coupled model of intermediate complexity, J. Geophys. Res.Atmos., 112, D06117, doi:10.1029/2006JD007316, 2007.

Kageyama, M., Mignot, J., Swingedouw, D., Marzin, C., Alkama, R., and Marti, O.: Glacial climate sensitivity to different states of the Atlantic Meridional Overturning Circulation: results from the IPSL model, Clim. Past, 5, 551-570, doi:10.5194/cp-5-5512009, 2009.

Kageyama, M., Paul, A., Roche, D. M., and Meerbeeck, C. J. V.: Modelling glacial climatic millennial-scale variability related to changes in the Atlantic meridional overturning circulation: a review, Quaternary Sci. Rev., 29, 2931-2956, 2010.

Kageyama, M., Merkel, U., Otto-Bliesner, B., Prange, M., AbeOuchi, A., Lohmann, G., Ohgaito, R., Roche, D. M., Singarayer, J., Swingedouw, D., and X Zhang: Climatic impacts of fresh water hosing under Last Glacial Maximum conditions: a multimodel study, Clim. Past, 9, 935-953, doi:10.5194/cp-9-9352013, 2013.

Khare, N.: Climatically sensitive 'Arctic': Another scientific frontier for India, Current Sci., 94, 176-178, 2008.

Krinner, G., Viovy, N., de Noblet-Ducoudre, N., Ogee, J., Polcher, J., Friedlingstein, P., Ciais, P., Sitch, S., and Prentice, I. C.: A dynamic global vegetation model for studies of the coupled atmosphere-biosphere system, Global Biogeochem. Cy., 19, GB1015, doi:10.1029/2003GB002199, 2005.

Kucharski, F., Bracco, A., Yoo, J. H., and Molteni, F.: Atlantic forced component of the Indian monsoon interannual variability, Geophys. Res. Lett., 35, L04706, doi:10.1029/2007GL033037, 2008.

Kucharski, F., Bracco, A., Yoo, J. H., Tompkins, A. M., Feudale, L., Ruti, P., and Dell'Aquila, A.: A Gill-Matsuno-type mechanism explains the tropical Atlantic influence on African and Indian monsoon rainfall, Q. J. Roy. Meteorol. Soc., 135, 569-579, 2009.

Kudrass, H. R., Hofmann, A., Doose, H., Emeis, K., and Erlenkeuser, H.: Modulation and amplification of climatic changes in the Northern Hemisphere by the Indian summer monsoon during the past 80 k.y., Geology, 29, 63-66, 2001.

Laj, C., Mazaud, A., and Duplessy, J. C.: Geomagnetic intensity and ${ }^{14} \mathrm{C}$ abundance in the atmosphere and ocean during the past 50 kyr, Geophys. Res. Lett., 23, 2045-2048, 1996.

Levitus, S., R. Burgett, and T. Boyer : World Ocean Atlas 1994, vol. 3, Salinity, NOAA Atlas NESDIS 3, U.S. Dept. of Commerce, Washington, DC, 1994.

Li, Y. F. and Harrison, S. P.: Simulations of the impact of orbital forcing and ocean on the Asian summer monsoon during the Holocene, Global Planet. Change, 60, 505-522, 2008.

Losada, T., Rodriguez-Fonseca, B., Polo, I., Janicot, S., Gervois, S., Chauvin, F., and Ruti, P.: Tropical response to the Atlantic Equatorial mode: AGCM multimodel approach, Clim. Dynam., 35, 45-52, 2010.

Lu, R. Y. and Dong, B. W.: Response of the Asian Summer Monsoon to Weakening of Atlantic Thermohaline Circulation, Adv. Atmos. Sci., 25, 723-736, 2008.

Lu, R. Y., Dong, B. W., and Ding, H.: Impact of the Atlantic multidecadal oscillation on the Asian summer monsoon, Geophys Res. Lett., 33, L24701, doi:10.1029/2006GL027655, 2006.

Madec, G., Delecluse, P., Imbard, M., and Levy, C.: OPA version 8.1 ocean general circulation model reference manual, LODYC/IPSL, Paris, France, p. 11, 1998.

Marti, O., Braconnot, P., Dufresne, J.-L., Bellier, J., Benshila, R., Bony, S., Brockmann, P., Cadule, P., Caubel, A., Codron, F., Denvil, S., Fairhead, L., Fichefet, T., Foujols, M. A., Friedlingstein, P., Goosse, H., Grandpeix, J. Y., Guilyardi, E., Hourdin, F., Idelkadi, A., Kageyama, M., Krinner, G., Levy, C., Madec, G., Musat, I., Swingedouw, D., and Talandier, C.: Key features of the IPSL ocean atmosphere model and its sensitivity to atmospheric resolution, Clim. Dynam., 34, 1-26, 2010. 
Marzin, C. and Braconnot, P.: Variations of Indian and African monsoons induced by insolation changes at 6 and $9.5 \mathrm{kyr}$ BP, Clim. Dynam., 33, 215-231, 2009.

Mathien-Blard, E. and Bassinot, F.: Salinity bias on the foraminifera $\mathrm{Mg} / \mathrm{Ca}$ thermometry: Correction procedure and implications for past ocean hydrographic reconstructions, Geochem. Geophy. Geosy., 10, Q12011, doi:10.1029/2008GC002353, 2009.

McManus, J., Oppo, D., and Cullen, J.: A 0.5-million-year record of millennial-scale climate variability in the North Atlantic, Science, 283, 971-975, 1999.

McManus, J. F., Francois, R., Gherardi, J.-M., Keigwin, K., and Brown-Leger, S.: Collapse and rapid resumption of Atlantic meridional circulation linked to deglacial climate changes, Nature, 428, 834-837, 2004.

Meese, D. A., Gow, A. J., Alley, R. B., Zielinski, G. A., Grootes, P. M., Ram, M., Taylor, K. C., Mayewski, P. A., and Bolzan, J. F.: The Greenland Ice Sheet Project 2 depth-age scale: Methods and results, J. Geophys. Res.-Oceans, 102, 26411-26423, 1997.

Merkel, U., Prange, M., and Schulz, M.: ENSO variability and teleconnections during glacial climates, Quaternary Sci. Rev., 29, 86-100, 2010.

Monnin, E., Indermuhle, A., Dallenbach, A., Fluckiger, J., Stauffer, B., Stocker, T. F., Raynaud, D., and Barnola, J. M.: Atmospheric $\mathrm{CO}_{2}$ concentrations over the last glacial termination, Science, 291, 112-114, 2001.

Ngo-Duc, T., Laval, K., Polcher, J., Lombard, A., and Cazenave, A.: Effects of land water storage on global mean sea level over the past half century, Geophys. Res. Lett., 32, L09704, doi:10.1029/2005GL022719, 2005.

Otto-Bliesner, B. L. and Brady, E. C.: The sensitivity of the climate response to the magnitude and location of freshwater forcing: last glacial maximum experiments, Quaternary Sci. Rev., 29, 56-73, 2010.

Overpeck, J. T., Webb, T., and Prentice, I. C.: Quantitative Interpretation of Fossil Pollen Spectra - Dissimilarity Coefficients and the Method of Modern Analogs, Quatern. Res., 23, 87-108, 1985.

Pausata, F. S. R., Battisti, D. S., Nisancioglu, K. H., and Bitz, C. M.: Chinese stalagmite $\delta^{18} \mathrm{O}$ controlled by changes in the Indian monsoon during a simulated Heinrich event, Nat. Geoscience, 4, 474-480, doi:10.1038/NGEO1169, 2011.

Peltier, W. R.: Global glacial isostasy and the surface of the iceage earth: The ice-5G (VM2) model and grace, Annu. Rev. Earth Planet. Sci., 32, 111-149, 2004.

Peterson, L. C., Haug, G. H., Hughen, K. A., and Röhl, U.: Rapid changes in the hydrologic cycle of the tropical North Atlantic during the last glacial, Science, 290, 1947-1951, 2000.

Porter, S. C. and An, Z. S.: Correlation Between Climate Events In The North-Atlantic And China During Last Glaciation, Nature, 375, 305-308, 1995.

Prell, W. L., Hutson, W. H., Williams, D. F., Be, A. W. H., Geitzenauer, K., and Molfino, B.: Surface Circulation of the Indian-ocean During the Last Glacial Maximum, Approximately 18,000 Yr Bp, Quatern. Res., 14, 309-336, 1980.

Prentice, I. C.: Multidimensional-scaling As A Research Tool In Quaternary Palynology - A Review of Theory and Methods, Rev. Palaeobot. Palynol., 31, 71-104, 1980.

Rashid, H., Flower, B. P., Poore, R. Z., and Quinn, T. M.: A similar to $25 \mathrm{ka}$ Indian Ocean monsoon variability record from the
Andaman Sea, Quaternary Sci. Rev., 26, 2586-2597, 2007.

Rohling, E. J., Liu, Q. S., Roberts, A. P., Stanford, J. D., Rasmussen, S. O., Langen, P. L., and Siddall, M.: Controls on the East Asian monsoon during the last glacial cycle, based on comparison between Hulu Cave and polar ice-core records, Quaternary Sci. Rev., 28, 3291-3302, 2009.

Rostek, F., Ruhland, G., Bassinot, F. C., Muller, P. J., Labeyrie, L. D., Lancelot, Y., and Bard, E.: Reconstructing Sea-surface Temperature and Salinity Using Delta-o-18 and Alkenone Records, Nature, 364, 319-321, 1993.

Rousseau, D. D. and Kukla, G.: Abrupt retreat of summer monsoon at the S1/L1 boundary in China, Global Planet. Change, 26, 189198, 2000.

Schmittner, A.: Decline of the marine ecosystem caused by a reduction in the Atlantic overturning circulation, Nature, 434, 628633, doi:10.1038/nature03476, 2005.

Schmittner, A., Galbraith, E. D., Hostetler, S. W., Pedersen, T. F., and Zhang, R.: Large fluctuations of dissolved oxygen in the Indian and Pacific oceans during Dansgaard-Oeschger oscillations caused by variations of North Atlantic Deep Water subduction, Paleoceanography, 22, PA3207, doi:10.1029/2006PA001384, 2007.

Schulz, H., von Rad, U., and Erlenkeuser, H.: Correlation between Arabian Sea and Greenland climate oscillations of the past 110,000 years, Nature, 393, 54-57, 1998.

Seager, R. and Battisti, D. S.: The General Circulation of the Atmosphere, chap. Challenges to our understanding of the general circulation: Abrupt climate change, Princeton University Press, 331-371, 2007.

Shackleton, N. J.: Attainment of isotopic equilibrium between ocean water and benthonic foraminifera genus Uvigerina: Isotopic changes in the ocean during the last glacial, Colloq. Int. C.N.R.S., 219, 203-209, 1974.

Singh, A., Jani, R. A., and Ramesh, R.: Spatiotemporal variations of the $\delta^{18} \mathrm{O}$-salinity relation in the northern Indian Ocean, DeepSea Res. Part I, 57, 1422-1431, 2010.

Sirocko, F., Sarnthein, M., Lange, H., and Erlenkeuser, H.: Atmospheric Summer Circulation and Coastal Upwelling In the Arabian Sea During the Holocene and the Last Glaciation, Quatern. Res., 36, 72-93, 1991.

Stocker, T. F. and Johnsen, S. J.: A minimum thermodynamic model for the bipolar seesaw, Paleoceanography, 18, 1087, doi:10.1029/2003PA000920, 2003.

Stouffer, R. J., Yin, J., Gregory, J. M., Dixon, K. W., Spelman, M. J., Hurlin, W., Weaver, A. J., Eby, M., Flato, G. M., Hasumi, H., Hu, A., Jungclaus, J. H., Kamenkovich, I. V., Levermann, A., Montoya, M., Murakami, S., Nawrath, S., Oka, A., Peltier, W. R., Robitaille, D. Y., Sokolov, A., Vettoretti, G., and Weber, S. L.: Investigating the causes of the response of the thermohaline circulation to past and future climate changes, J. Climate, 19, 13651387, 2006.

Stuiver, M. and Reimer, P. J.: Extended ${ }^{14} \mathrm{C}$ Data-base and Revised Calib 3.0 ${ }^{14} \mathrm{C}$ Age Calibration Program, Radiocarbon, 35, 215230, 1993.

Stuiver, M., Reimer, P. J., and Braziunas, T. F.: High-precision radiocarbon age calibration for terrestrial and marine samples, Radiocarbon, 40, 1127-1151, 1998.

Swingedouw, D., Mignot, J., Braconnot, P., Mosquet, E., Kageyama, M., and Alkama, R.: Impact of Freshwater Release 
in the North Atlantic under Different Climate Conditions in an OAGCM, J. Climate, 22, 6377-6403, 2009.

Thouveny, N., Debeaulieu, J. L., Bonifay, E., Creer, K. M., Guiot, J., Icole, M., Johnsen, S., Jouzel, J., Reille, M., Williams, T., and Williamson, D.: Climate Variations In Europe Over The Past 140-Kyr Deduced From Rock Magnetism, Nature, 371, 503$506,1994$.

Tierney, J. E. and Russell, J. M.: Abrupt climate change in southeast tropical Africa influenced by Indian monsoon variability and ITCZ migration, Geophys. Res. Lett., 34, L15709, doi:10.1029/2007GL029508, 2007.

Timmermann, A., Okumura, Y., An, S. I., Clement, A., Dong, B., Guilyardi, E., Hu, A., Jungclaus, J. H., Renold, M., Stocker, T. F., Stouffer, R. J., Sutton, R., Xie, S. P., and Yin, J.: The influence of a weakening of the Atlantic meridional overturning circulation on ENSO, J. Climate, 20, 4899-4919, 2007.

Valcke, S.: OASIS3 user guide (prism_2-5), PRISM support initiative 3, http://www.prism.enes.org/Publications/Reports/oasis3_ UserGuide_T3.pdf (last access: December 2012), 68 pp., 2006.

van der Plicht, J., Beck, J. W., Bard, E., Baillie, M. G. L., Blackwell, P. G., Buck, C. E., Friedrich, M., Guilderson, T. P., Hughen, K. A., Kromer, B., McCormac, F. G., Ramsey, C. B., Reimer, P. J., Reimer, R. W., Remmele, S., Richards, D. A., Southon, J. R., Stuiver, M., and Weyhenmeyer, C. E.: NotCal04 - Comparison/calibration ${ }^{14} \mathrm{C}$ records $26-50$ cal kyr BP, Radiocarbon, 46, 1225-1238, 2004.

Van Campo, E. and Gasse, F.: Pollen-inferred and Diatom-inferred Climatic and Hydrological Changes In Sumxi Co Basin (western Tibet) Since 13,000 Yr Bp, Quatern. Res., 39, 300-313, 1993.

Van Campo, E., Cour, P., and Hang, S. X.: Holocene environmental changes in Bangong Co basin (western Tibet), 2. The pollen record, Palaeogeogr. Palaeocl., 120, 49-63, 1996.

Varkey, M. J., Murty, V. S. N., and Suryanarayana, A.: Oceanography and Marine Biology: an Annual Review, chap. Physical oceanography of the Bay of Bengal and Andaman Sea, UCL Press, 1-70, 1996.

Vellinga, M. and Wood, R. A.: Global climatic impacts of a collapse of the Atlantic thermohaline circulation, Climatic Change, 54, 251-267, 2002.

Voelker, A., Sarnthein, M., Grootes, P., Erlenkeuser, H., Laj, C., Mazaud, A., Nadeau, M.-J., and Schleicher, M.: Correlation of marine ${ }^{14} \mathrm{C}$ ages from the Nordic Sea with the GISP2 isotope record: Implications for ${ }^{14} \mathrm{C}$ calibration beyond $25 \mathrm{ka} \mathrm{BP}$, Radiocarbon, 40, 517-534, 1998.

Waelbroeck, C., Labeyrie, L., Michel, E., Duplessy, J. C., McManus, J. F., Lambeck, K., Balbon, E., and Labracherie, M.: Sealevel and deep water temperature changes derived from benthic foraminifera isotopic records, Quaternary Sci. Rev., 21, 295-305, 2002.
Wang, Y. J., Cheng, H., Edwards, R. L., An, Z. S., Wu, J. Y., Shen, C. C., and Dorale, J. A.: A high-resolution absolute-dated Late Pleistocene monsoon record from Hulu Cave, China, Science, 294, 2345-2348, 2001.

Wang, X., Auler, A. S., Edwards, R. L., Cheng, H., Cristalli, P. S., Smart, P. L., Richards, D. A., and Shen, C.-C.: Wet periods in northeastern Brazil over the past 210 kyr linked to distant climate anomalies, Nature, 432, 740-743, 2004.

Wu, R. G. and Kirtman, B. P.: Observed relationship of spring and summer East Asian rainfall with winter and spring Eurasian snow, J. Climate, 20, 1285-1304, 2007.

Xavier, P. K., Marzin, C., and Goswami, B. N.: An objective definition of the Indian summer monsoon season and a new perspective on the ENSO-monsoon relationship, Q. J. Roy. Meteorol. Soc., 133, 749-764, 2007.

Xiao, J. L., Porter, S. C., An, Z. S., Kumai, H., and Yoshikawa, S.: Grain-size of Quartz As An Indicator of Winter Monsoon Strength On the Loess Plateau of Central China During the Last 130,000-yr, Quatern. Res., 43, 22-29, 1995.

Xiao, J. L., An, Z. S., Liu, T. S., Inouchi, Y., Kumai, H., Yoshikawa, S., and Kondo, Y.: East Asian monsoon variation during the last 130,000 Years: evidence from the Loess Plateau of central China and Lake Biwa of Japan, Quaternary Sci. Rev., 18, 147-157, 1999.

Yanase, W. and Abe-Ouchi, A.: The LGM surface climate and atmospheric circulation over East Asia and the North Pacific in the PMIP2 coupled model simulations, Clim. Past, 3, 439-451, doi:10.5194/cp-3-439-2007, 2007.

Zhang, R. and Delworth, T. L.: Simulated tropical response to a substantial weakening of the Atlantic thermohaline circulation, J. Climate, 18, 1853-1860, 2005.

Zhang, R. and Delworth, T. L.: Impact of Atlantic multidecadal oscillations on India/Sahel rainfall and Atlantic hurricanes, Geophys. Res. Lett., 33, L17712, doi:10.1029/2006GL026267, 2006.

Ziegler, M., Lourens, L. J., Tuenter, E., Hilgen, F., Reichart, G.-J., and Weber, N.: Precession phasing offset between Indian summer monsoon and Arabian Sea productivity linked to changes in Atlantic overturning circulation, Paleoceanography, 25, PA3213, doi:10.1029/2009PA001884, 2010

Zonneveld, K. A. F., Ganssen, G., Troelstra, S., Versteegh, G. J. M., and Visscher, H.: Mechanisms forcing abrupt fluctuations of the Indian Ocean summer monsoon during the last deglaciation, Quaternary Sci. Rev., 16, 187-201, 1997. 